\title{
Washback Effect of High-Stakes English Language Tests on the Learning Behaviours of Ghanaian ESL Learners
}

\author{
Sefa Owusu \\ Department of Applied Linguistics, University of Education, Winneba, Ghana
}

\begin{abstract}
The term washback or backwash is used in Applied Linguistics to refer to the impact of second/foreign language testing on learning behaviours, teaching practices, and curriculum design. The Basic Education Certificate Examination (BECE) and the West African Senior School Certificate Examination (WASSCE) English language tests administered by the West African Examinations Council (WAEC) are high-stakes tests which have very important consequences for the junior and senior high school leavers. The English language syllabus for both junior high school and senior high school levels has listening, reading, writing, and speaking components. Unfortunately, the BECE and WASSCE English language tests do not assess students on all the language skills. Although the WASSCE English language test has oral English component (which was introduced in 1999), it assesses candidates on listening comprehension only. Since teachers and students are likely to concentrate on what is going to be assessed, there may be negative washback effect on teaching and learning of English language in junior and senior high schools in Ghana. This paper reports on the washback effect of high-stakes English language tests on the learning behaviours of Ghanaian ESL learners. A total of 344 students from 3 junior high and 5 senior high schools were purposively sampled for the study. Qualitative and quantitative analysis of data revealed that the BECE/WASSCE influenced how students learnt English, and that they wanted their teachers to concentrate on language areas that would only make them perform well in the high-stakes tests. This confirms the Alderson and Wall's washback hypotheses that a test will influence what and how learners learn.
\end{abstract}

DOI: $10.7176 / \mathrm{JEP} / 12-30-10$

Publication date:October $31^{\text {st }} 2021$

\subsection{Washback: What is it?}

According to Alderson \& Wall (1993), washback or backwash refers to the influence of testing on teaching and learning. Popham (1987) uses the term measurement-driven instruction to refer to the notion that testing influences teaching and learning. This idea that examinations tend to have some impact, directly or indirectly, on the curriculum or teaching and learning is not new in Applied Linguistics and Education (Alderson 1986, Pearson 1988, Hughes 1989, Khaniya 1990). Although the operation of testing is distinct from teaching, testing tends to have impact on teaching and learning. According to Pearson (1988), public examinations influence the attitudes, behaviour, and motivation of teachers, learners, and parents. What is assessed always becomes what is valued, which becomes what is taught (McEwen 1995:42). Examinations can be used as a means of promoting curriculum change, as teachers tend to ignore subject areas and activities that do not contribute directly to passing examinations. Examinations therefore have the tendency of distorting the curriculum (Vernon 1956), thereby bringing about negative washback. Current research on the impact of examinations on the curriculum focuses on positive washback. This is because it is hoped that proper or well-designed language tests can go a long way to improve the quality of classroom teaching and learning.

Although the washback phenomenon was acknowledged before 1993, (Alderson 1986, Pearson 1988, Hughes 1989, Khaniya 1990), not much attention was paid to identifying the nature of washback until Alderson and Wall (1993). They investigated the effect of the introduction of new tests in Sri Lanka on the teaching of English as a foreign language by secondary school teachers, and posited the following possible washback hypotheses:

1) A test will influence teaching

2) A test will influence learning

3) A test will influence what teachers teach

4) A test will influence how teachers teach

5) A test will influence what learners learn

6) A test will influence how learners learn

7) A test will influence the rate and sequence of teaching

8) A test will influence the rate and sequence of learning

9) A test will influence the degree and depth of teaching

10) A test will influence the degree and depth of learning

11) A test will influence attitudes to content, method, etc. of teaching/learning

12) Tests that have important consequences will have washback

13) Tests that do not have important consequences will have no washback

14) Tests will have washback on all learners and teachers 
15) Tests will have washback effects for some teachers and some learners, but not for others.

(Alderson \& Wall, 1993a:120-121)

It was not, however, the intention of Alderson \& Wall to provide empirical evidence to confirm all these hypotheses. The washback hypotheses were meant to lay the foundation for research questions that washback studies would seek to address in future.

\subsection{Washback in Language Testing}

Washback refers to the effect of testing on teaching and learning (Hughes, 1989) or the unforeseen side-effects of testing (Spolsky 1994). It is a fact that cannot be denied that the process of teaching and learning can be affected by tests. Traditionally, tests should come at the end of teaching and learning process (Cheng, 1997). However, it seems that the direction has been changed. Teachers and learners nowadays consider testing or examinations before teaching and learning process. Testing now determines what is taught and learnt. Teaching and learning strategies are always altered to agree with the demands the test. We cannot blame teachers and learners too much if they adapt their teaching and learning respectively to reflect the demands of the test, because every normal student aims at obtaining good grades in high-stakes tests. What is important is that test designers should make every endeavour to match the curriculum and assessment. There should not be any gap between the prescribed curriculum and the assessment. If the test is not aligned with the curriculum, teachers will certainly teach to the test and the test will be used to control the curriculum, which can result in unexpected, harmful consequences.

\subsection{Negative Washback}

Washback can be negative. Negative washback refers to the unexpected, harmful consequences of a test. According to Bailey (1996), negative washback effect impedes the accomplishment of educational goals, as there is a mismatch between the stated goals of the curriculum and the focus of assessment. When there is less or no correlation between curriculum goals and focus of assessment, teachers and learners abandon the curriculum goals in favour of test preparation. In the words of Madaus (1988:83), it is testing, not the official stated curriculum, that is increasingly determining what is taught, how it is taught, what is learned, and how it is learned. What this means is that assessment is used, inadvertently, to drive the curriculum, teaching methods, and students' approaches to learning. When this happens, teachers and students begin to narrow the curriculum to those areas most likely to be tested. It is believed that the easiest way to change students' learning is to change assessment system, and not the curriculum (Elton and Laurillard, 1979). It is this assessment driven curriculum that leads to a negative washback effect, which can go a long way to, adversely, affect learners' communicative competence.

\subsection{Positive Washback}

A well-designed test should encourage good teaching and promote the accomplishment of the desired goals of the curriculum. A test that has positive influence on students and stakeholders in education can be said to have positive washback effect. According to Bachman (1990), positive washback occurs when testing reflects the skills and content taught in the classroom. Every good test designer or examiner would like to use tests to make students pay more attention to learning. Unfortunately, high-stakes tests often put pressure on teachers and students, thereby reducing classroom instruction to practicing test-related techniques rather than language learning activities. A test that has washback validity does not impede the accomplishment of educational goals. Tests should be designed in such a way that it will not be easy for teachers and students to use them to drive the curriculum. Positive washback occurs when there is a very strong correlation between the curriculum goals and the focus of the test.

\subsection{Examinations Conducted by the WAEC}

The West African Examinations Council (WAEC) was established in 1952 after the Governments of Gold Coast (now Ghana), Nigeria, Sierra Leone, and The Gambia enacted the West African Examinations Council Ordinances in 1951. Liberia later joined the Council in 1974. The main objectives of the Council are conducting of examinations and awarding of certificates. The WAEC conducts the following examinations in the member countries:

$>$ Basic Education Certificate Examination (BECE)

$>$ West African Senior School Certificate Examination (WASSCE)

$>$ General Business Certificate Examination (GBCE).

The BECE is conducted for both certification and selection to Senior High Schools and Technical Institutions. This examination, which is conducted nationwide in June each year in Ghana, is eligible for candidates in the third year of Junior High Schools approved by the Ghana Education Service. The following are the subjects for the Basic Education Certificate Examination:

$>$ English Language

$>$ Ghanaian Language and Culture

$>$ Social Studies 
$>$ Integrated Science

$>$ Mathematics

$>$ Basic Design and Technology

$>$ Information and Communication Technology

$>$ French (optional)

$>$ Religious and Moral Education

The WASSCE is administered to school candidates in the third year of their West African Senior School courses and to private candidates. The examination is meant for both selection to tertiary institutions and for certification. It is conducted in May and June (for school candidates) and October and November (for private candidates) each year. Candidates for any of the programmes (Agriculture, Business, Technical, Vocational, Arts, and Science) are required to take the following core subjects:

$>$ English Language

$>$ Integrated Science

$>$ Mathematics (Core)

$>$ Social Studies

1.5 The WAEC English Language Test and Washback

Languages are usually taught and assessed in terms of the four basic skills: listening, speaking, reading, and writing. Ideally, the BECE/WASSCE should be able to test students on all these language skills, as specified in the official English language curriculum. According to Powers (2010), it is important to test for each of these four skills individually because each is a critical aspect of communicative competence. Unfortunately, not all of them are covered in the BECE/WASSCE. The English language syllabus (for both BECE and WASSCE) issued by the Curriculum Research and Development Division (CRDD) of the Ministry of Education is designed to assist students to:

$>$ develop the language skills of listening, speaking, reading, and writing.

$>$ generate in students the love for reading for pleasure and the development of creative potentials.

$>$ improve the communicative competence of students and give them the confidence to communicate.

$>$ enable students to communicate effectively through the speaking and writing of English.

The study of English at both junior and senior high levels comprises Language and Literature. The Language component is an integration of both the receptive (listening and reading) and productive (speaking and writing) skills in English. Learners use the receptive skills (listening and reading) to receive information (for knowledge and understanding). The productive skills (speaking and writing), on other hand, are used to give information (for use of knowledge). Knowledge and Understanding refers to the ability to identify and recall which is done through listening and reading. Use of Knowledge implies the ability to use the language in writing and in speaking. These two profile dimensions (Knowledge and Understanding and Use of Knowledge) and the four language skills have been specified for teaching, learning and testing in the English language syllabus as shown in Table 1 below:

Table 1: Relationship between Profile Dimensions and Language Skills

\begin{tabular}{|l|lc|lc|c|}
\hline Profile Dimensions & \multicolumn{2}{|l}{ Receptive Skills } & \multicolumn{2}{l|}{ Productive Skills } & Total \\
& Listening & Reading & Speaking & Writing & \\
\hline Knowledge and Understanding & $10 \%$ & $30 \%$ & & & $40 \%$ \\
\hline Use of Knowledge & & & $30 \%$ & $30 \%$ & $60 \%$ \\
\hline Total & $10 \%$ & $30 \%$ & $30 \%$ & $30 \%$ & $100 \%$ \\
\hline
\end{tabular}

Source: Curriculum Research and Development Division (2012), page viii

The English language syllabus for the BECE requires that $10 \%$ of teaching, learning, and testing should be devoted to listening skills, and 30\% should be given to each of the other three language skills (reading, speaking, and writing skills). That of the WASSCE requires that 5\% should be devoted to listening skills, $35 \%$ to reading skills, 30\% to speaking skills, and 30\% to writing skills. The last but one row, shows the marks allocated to each of the four skills. Only 5\% is allocated to listening skills at the senior high school level because it is expected that students would have acquired a lot of the skills in listening to spoken English. If the content or focus of the BECE or WASSCE is different from these requirements of the English language syllabus, teachers and learners can adjust their behaviour in order to meet the demands of the examination.

\subsection{Literature Review}

Following the first empirical washback study by Alderson \& Wall (1993a), many washback studies have been carried out in different settings by different researchers:

$>$ Israel: Shohamy, Donitsa-Schmidt \& Ferman (1996)

$>$ Japan: Watanabe (1996)

$>$ Sri Lanka: Wall (1996)

$>$ U.S.A: Alderson \& Hamp-Lyons (1996) 
$>$ Hong Kong: Cheng (1997), (1999)

$>$ New Zealand: Hayes \& Read (2004)

$>$ U.K: Scott (2007) Green (2007)

$>$ Taiwan: Shih (2007), Hsiu-yu Chu (2009)

$>$ New Zealand: Mizutani (2009)

$>$ China: Peng (2011)

$>$ Libya: Onaiba (2013)

$>$ Iran: Ghorbani \& Neissari (2015)

These studies of washback effects in language testing have either investigated the impact of high-stakes language testing programmes or researched into how changes in systems of these tests affect teaching and learning.

Several high-stakes standardized tests have received some treatment in the washback studies. Shohamy, et al. (1996) examined the impact of national tests of Arabic as a Second Language (ASL) and English as a Foreign Language (EFL) in Israel. They found out that washback changes over time because of factors including language status and test uses. Alderson \& Hamp-Lyons (1996) also investigated the influence of Test of English as a Foreign Language (TOEFL) on classroom teaching. According to Alderson \& Hamp-Lyons (1996) TOEFL affects both what and how teachers teach, but the effect varies with teachers. Cheng (1999) investigated the possible washback effects from the 1994 revised Hong Kong Certificate of Education Examination in English (HKCEE) on teachers and students in Hong Kong secondary schools. It was found out that the change on teaching content rather than methodology was attributed to inadequate training and qualifications of secondary English teachers. Green (2007) investigated whether test preparation classes were advantageous in assisting students trying to improve their International English Language Testing System (IELTS) writing scores. He concluded that test preparation classes had no apparent benefit to improve test scores. Shih (2007) also explored the effects of General English Proficiency Test (GEPT) exit requirements on learning, and concluded that the current washback theory didn't account for GEPT washback.

In Ghana, some attempts have been made to investigate the effects of assessment on teaching and learning. For instance, Oduro-Okyireh \& Narh-Kwao (2014) look at the extent to which assessment in general promotes effective teaching and also influences classroom learning in the Ashanti Mampong Municipality of the Ashanti Region of Ghana. According to the study, teachers' classroom assessments improve learning. Nothing is said about whether or not the teachers focus their attention on preparing the students for the assessment.

Agbeti (2011) considers the influence of external assessment on teaching and learning in junior high schools in Ghana. He concludes that the examination influences what teachers teach and how they teach it and the teachers' self-worth, prestige and public esteem depend on the performance of their students in the examination.

Unlike Oduro-Okyireh \& Narh-Kwao (2014) and Agbeti (2011), who focus their attention on the effects of assessment in general on teaching and learning, Ofori-Bekoe (2006) evaluates the impact of the Senior Secondary School Certificate Examination (SSSCE) on the Social Studies curriculum as a whole, with specific reference to teachers' classroom practices, curriculum content, its implementation and students' attainment. He concludes that the SSSCE does not adequately cover all the goals and objectives of Social Studies in Ghana and that it has a constraining impact on teachers' classroom practices.

An examination of the related literature shows that some studies have been conducted on the effects of assessment (in general) on stakeholders in education and on teaching and learning in Ghana. However, washback effect of external examinations on teaching and learning of English language in Ghana has received virtually no attention. It is for this reason that this study (which may be the first of its kind in Ghana) has been undertaken.

\subsection{Methodology}

The study employs the use of questionnaires and interviews. A questionnaire was employed to collect data from 344 students who were being prepared for BECE or WASSCE. The questionnaire for students, which was simplified and reduced to their level of understanding, was made up of 20 close-ended and 8 open-ended items. The questionnaire was piloted with 120 students from Morning Star School in Accra, Uncle Rich School at Winneba, Adisadel College in Cape Coast, and Saint Augustine's College in Cape Coast to find out whether the items were valid. The items were found to be comprehensive enough to collect all the information needed to address the research question: How does the BECE/WASSCE English language test influence the learning behaviours of students?

A total of 344 students from 3 junior high and 5 senior high schools were purposively sampled for the study. All the available senior high school students were second year students. On the other hand, the junior high students were made up of 77 second year students and 116 final year students. Table 2 below shows the schools that were sampled for the study. 
Table 2: Schools Sampled for the Study

\begin{tabular}{|l|l|l|}
\hline School & Number of Students & Level/Class \\
\hline Wesley Girls' High School & 51 & SHS 2 \\
\hline Aggrey Memorial A.M.E. Zion Senior High School & 50 & SHS 2 \\
\hline Obrachire Senior High Technical School & 50 & SHS 2 \\
\hline West End International School & 50 & JHS 3 \\
\hline Saint Patrick's Junior High School & 66 & JHS 3 \\
\hline Saint Mary's Anglican Junior High School & 77 & JHS 2 \\
\hline
\end{tabular}

In addition to this number, 30 students ( 5 final year students from each of the schools) were interviewed to gather additional data on the attitudes of students towards language areas or skills that are not examined. It was hypothesised that students would not give the required attention to language areas or skills that are not covered in the BECE/WASSCE and that their attitudes would not be influenced by their class levels.

\subsection{Data Analysis and Presentation}

\subsubsection{The Language Areas Students Expect Teachers to Focus on}

This section analyses the views of students on whether or not they want their teachers to teach them only language areas or skills that would make them perform well at the BECE/WASSCE. Table 3 and Fig 1 below show the summary of the students' responses to the questionnaire item 1 (Our teachers should teach language areas that will only make us perform well at the BECE/WASSCE). 136 and 198 of the students agree and strongly agree respectively with the statement. This means that they want their teachers to concentrate on language areas that will only make them perform well in their final examinations.

Table 3: Our teachers should teach language areas that will only make us perform well at the BECE/WASSCE.

\begin{tabular}{|c|c|c|c|c|c|c|c|}
\hline \multicolumn{8}{|c|}{ Crosstab } \\
\hline & & & \multicolumn{4}{|c|}{ Q1 } & \multirow[b]{2}{*}{ Total } \\
\hline & & & $\mathrm{D}$ & $\mathrm{U}$ & $\mathrm{A}$ & $\mathrm{SA}$ & \\
\hline \multirow{2}{*}{\multicolumn{2}{|c|}{ JHS 2}} & Count & 0 & 0 & 29 & 48 & 77 \\
\hline & & Expected Count & 1.3 & .9 & 30.4 & 44.3 & 77.0 \\
\hline \multirow{2}{*}{\multicolumn{2}{|c|}{$\overline{J H S ~} 3$}} & Count & 0 & 0 & 51 & 65 & 116 \\
\hline & & Expected Count & 2.0 & 1.3 & 45.9 & 66.8 & 116.0 \\
\hline \multirow{2}{*}{\multicolumn{2}{|c|}{$\overline{\text { SHS } 2}$}} & Count & 6 & 4 & 56 & 85 & 151 \\
\hline & & Expected Count & 2.6 & 1.8 & 59.7 & 86.9 & 151.0 \\
\hline \multirow[t]{2}{*}{ Total } & & Count & 6 & 4 & 136 & 198 & 344 \\
\hline & & Expected Count & 6.0 & 4.0 & 136.0 & 198.0 & 344.0 \\
\hline
\end{tabular}

Fig 1: Our teachers should teach language areas that will only make us perform well at the BECE/WASSCE.

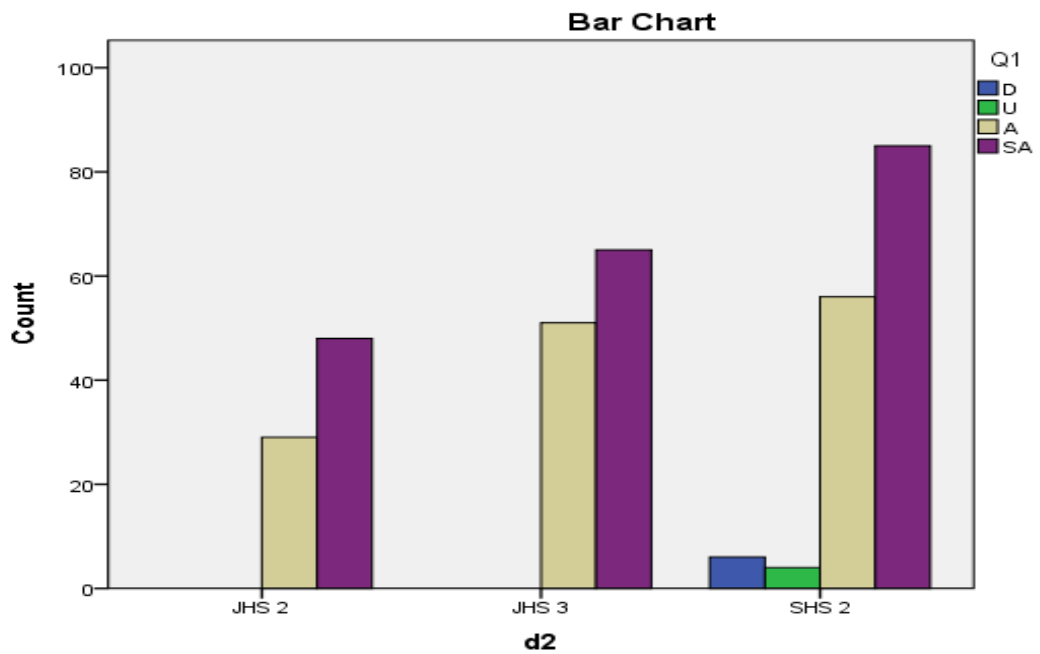

Table 4 below shows the Chi-Square Tests. The $\boldsymbol{d} \boldsymbol{f}$ (degree of freedom) and the Value of 6 and 14.049 respectively mean that there is no significant difference between the expected frequencies and the observed frequencies. The result confirms the null hypothesis that the students would like their teachers to teach language areas that are covered in the BECE/WASSCE. The analyses of the students' responses to questionnaire item 1 
showed that the students agreed that their teachers should teach them language areas that would only make them perform well at the BECE/WASSCE. They therefore wanted their teachers to concentrate on language areas or skills that would only make them perform well at the final examinations.

Table 4: Chi-Square Analysis of Questionnaire Item 1

Chi-Square Tests

\begin{tabular}{|l|r|r|r|}
\hline & Value & df & Asymp. Sig. (2-sided) \\
\hline Pearson Chi-Square & $14.049^{\mathrm{a}}$ & 6 & .029 \\
Likelihood Ratio & 17.713 & 6 & .007 \\
Linear-by-Linear Association & 4.108 & 1 & .043 \\
N of Valid Cases & 344 & & \\
\hline
\end{tabular}

a. 6 cells $(50.0 \%)$ have expected count less than 5 . The minimum expected count is .90 .

Table 5 also shows the analysis of the students' responses to the questionnaire item 1in respect of percentage, mean, and standard deviation. The standard deviation of $\mathbf{. 4 9 4}$ for BECE shows that the responses of JHS students did not differ much from one another. The BECE candidates were almost saying the same thing. They wanted their teachers to teach them examinable areas. On the other hand, the standard deviation of $\mathbf{7 3 7}$ for WASSCE shows that the views of the SHS students differed slightly from one another compared with that of the JHS students. 4\% of the SHS students disagreed with the statement while 2.2\% were undecided. Again the mean of 4.59 and 4.46 for BECE and WASSCE respectively shows that the BECE candidates tended to put more pressure on their teachers to concentrate on examinable areas than the WASSCE candidates.

Table 5: Summary of Students' Responses to Questionnaire Item 1

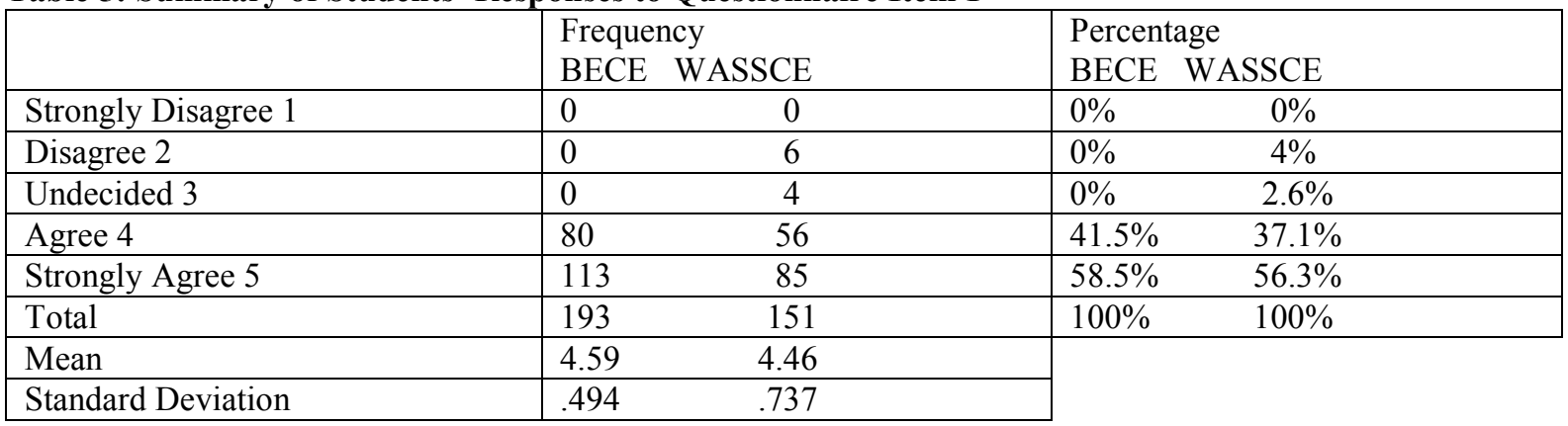

\subsubsection{The Impact of the BECE/WASSCE English Language Test on how Students Learn English}

According to Alderson \& Wall, (1993) a test will influence how learners learn. That is, a test will influence the way or manner learners learn; learners may not be able to learn in a relaxed manner because of the test. It is this tension that causes learners to develop negative attitudes towards high-stakes tests. This section analyses the views of students on how they will learn English if there is no BECE/WASSCE. Table 6 and Fig 2 below show the analysis of students' views on questionnaire item 3. (If there is no BECE/WASSCE, how I learn will be different). The results show that the BECE/WASSCE influences how students learn English. None of the students disagreed with the statement and 5 were undecided. 174 and 165 agreed and strongly disagreed respectively with the statement. Table 7 shows the Chi-Square Tests of the students' views on how the BECE/WASSCE influences how they learn English. The Pearson Chi-Square value of $\mathbf{4 . 7 7 8}^{\mathrm{a}}$ means that expected frequencies are not different from the observed frequencies.

Table 6: If there is no BECE/WASSCE, how I learn will be different.

Crosstab

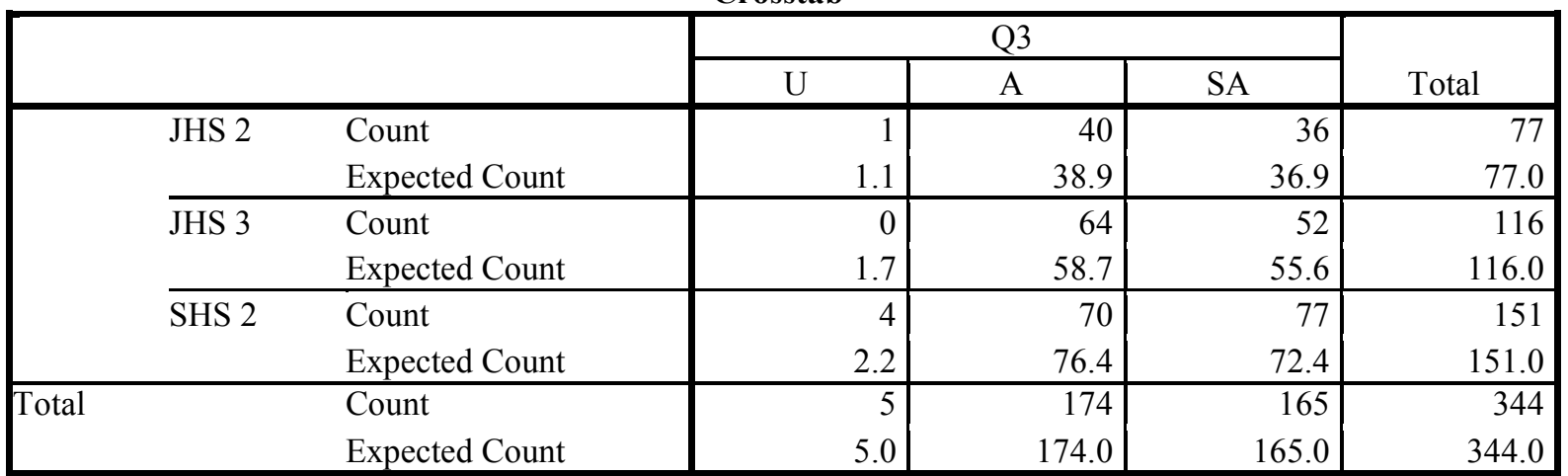


Fig 2: If there is no BECE/WASSCE, how I learn will be different.

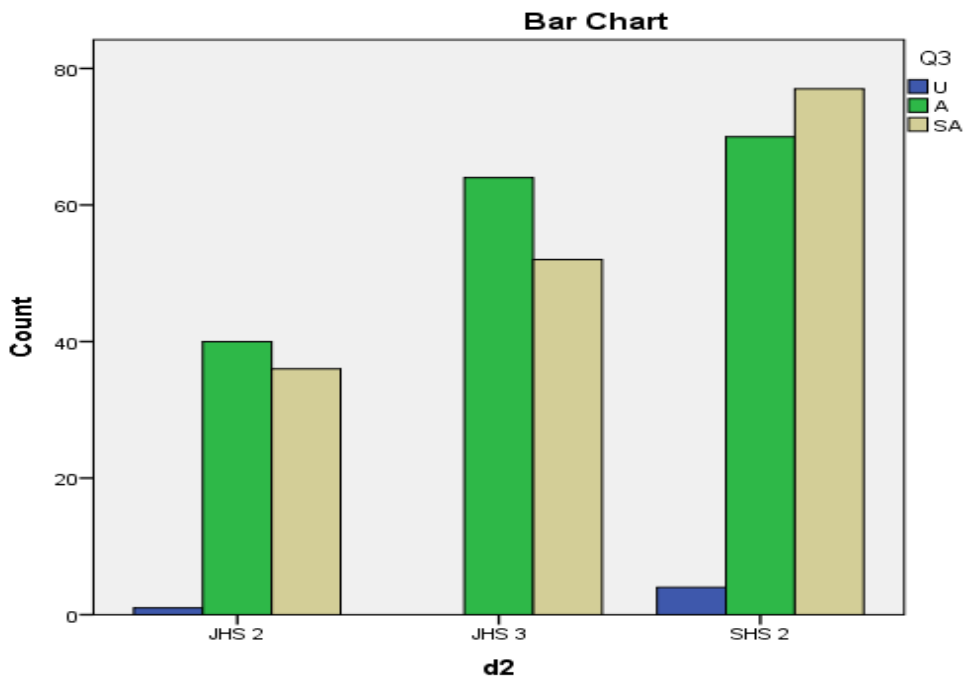

Table 7: Chi-Square Analysis of Questionnaire Item 3

Chi-Square Tests

\begin{tabular}{|l|r|r|r|}
\hline & Value & df & Asymp. Sig. (2-sided) \\
\hline Pearson Chi-Square & $4.778^{\mathrm{a}}$ & 4 & .311 \\
Likelihood Ratio & 6.172 & 4 & .187 \\
Linear-by-Linear Association & .217 & 1 & .641 \\
N of Valid Cases & 344 & & \\
\hline
\end{tabular}

a. 3 cells (33.3\%) have expected count less than 5 . The minimum expected count is 1.12 .

Further analysis of students' views on how the BECE/WASSCE influences how students learn English is presented in Table 8 below. None of the students disagreed with the statement. $0.5 \%$ and $2.6 \%$ of BECE and WASSCE candidates respectively were undecided. The analysis shows that both BECE and WASSCE influenced how the students learned English. However, the mean of 4.48 and standard deviation of .552 for WASSCE are slightly higher than that of BECE with the mean of 4.45 and standard deviation of 509 . It can therefore be concluded that when it comes to how students learn English, there is not much difference between the JHS students and the SHS students in the study.

Table 8: Summary of Students' Responses to Questionnaire Item 3

\begin{tabular}{|c|c|c|c|c|}
\hline & \multicolumn{2}{|c|}{$\begin{array}{l}\text { Frequency } \\
\text { BECE WASSCE }\end{array}$} & \multicolumn{2}{|c|}{$\begin{array}{l}\text { Percentage } \\
\text { BECE WASSCE }\end{array}$} \\
\hline Strongly Disagree 1 & 0 & 0 & $0 \%$ & $0 \%$ \\
\hline Disagree 2 & 0 & 0 & $0 \%$ & $0 \%$ \\
\hline Undecided 3 & 1 & 4 & $.5 \%$ & $2.6 \%$ \\
\hline Agree 4 & 104 & 70 & $53.9 \%$ & $46.4 \%$ \\
\hline Strongly Agree 5 & 88 & 77 & $45.6 \%$ & $51.0 \%$ \\
\hline Total & 193 & 151 & $100 \%$ & $100 \%$ \\
\hline Mean & 4.45 & 4.48 & & \\
\hline Standard Deviation & .509 & .552 & & \\
\hline
\end{tabular}

\subsubsection{Students' attention on language areas that are not examined in the BECE/WASSCE.}

This section analyses the views of students on the kind of attention given to language areas or skills that are not examined in the BECE/WASSCE. Table 9 below shows the summary of students' responses to the questionnaire item 5. (Students should focus their attention on language areas that are examined in the BECE/WASSCE.) None of the students disagreed with the statement. 180 and 144 agreed and strongly agreed respectively with the statement, while 20 were undecided. The graphical presentation of the summary of the views of the students is shown in Fig 3 below. The analysis of the views of the students shows that the students would like to focus their attention on language areas that are examined in the BECE/WASSCE. Although 20 students were undecided, the results of Chi-Square Tests (Value: $\mathbf{2 3 . 7 5 0}^{\mathbf{a}}$; df: 4), as shown in Table 10, indicate that the expected frequencies are not too different from the observed frequencies. Although both JHS and SHS students focused their attention on language skills and areas that are covered in the BECE/WASSCE, the results as shown in Table 11 indicate that the BECE candidates focused their attention on the examinable areas more than the WASSCE candidates. The 
mean and the standard deviation of $\mathbf{4 . 4 4}$ and $\mathbf{. 5 0 8}$ respectively for BECE are higher than that of the WASSCE with the mean and the standard deviation of $\mathbf{4 . 2 6}$ and .668 respectively.

Table 9: Students should focus their attention on language areas that are examined in the BECE/WASSCE. Crosstab

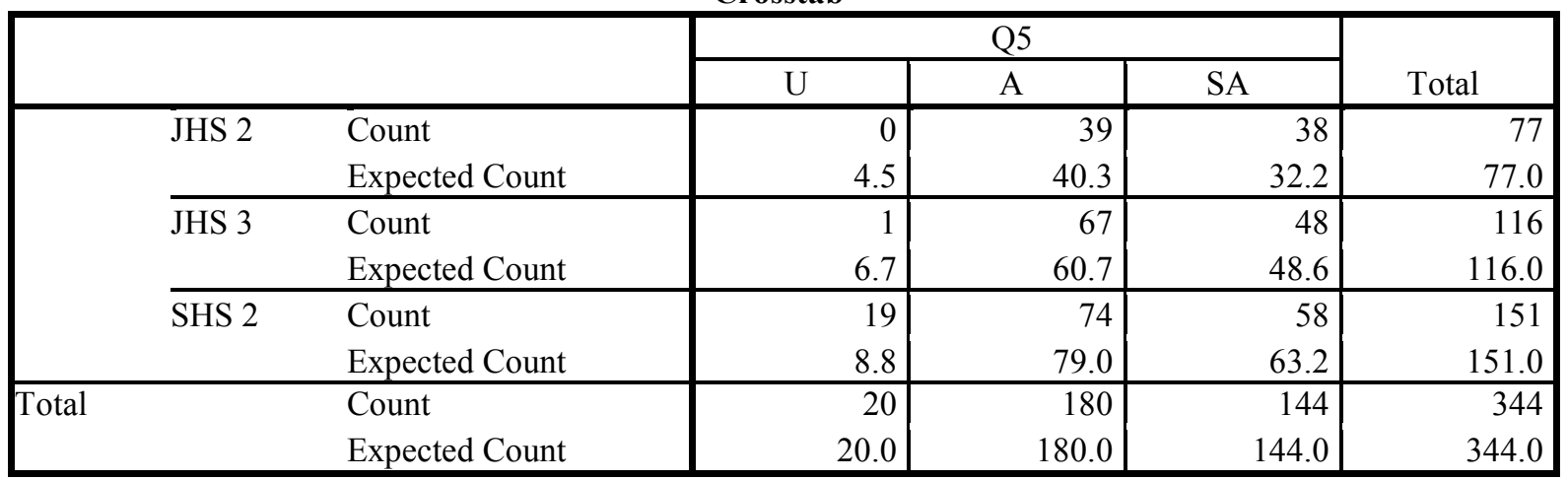

Fig 3: Students should focus their attention on language areas that are examined in the BECE/WASSCE.

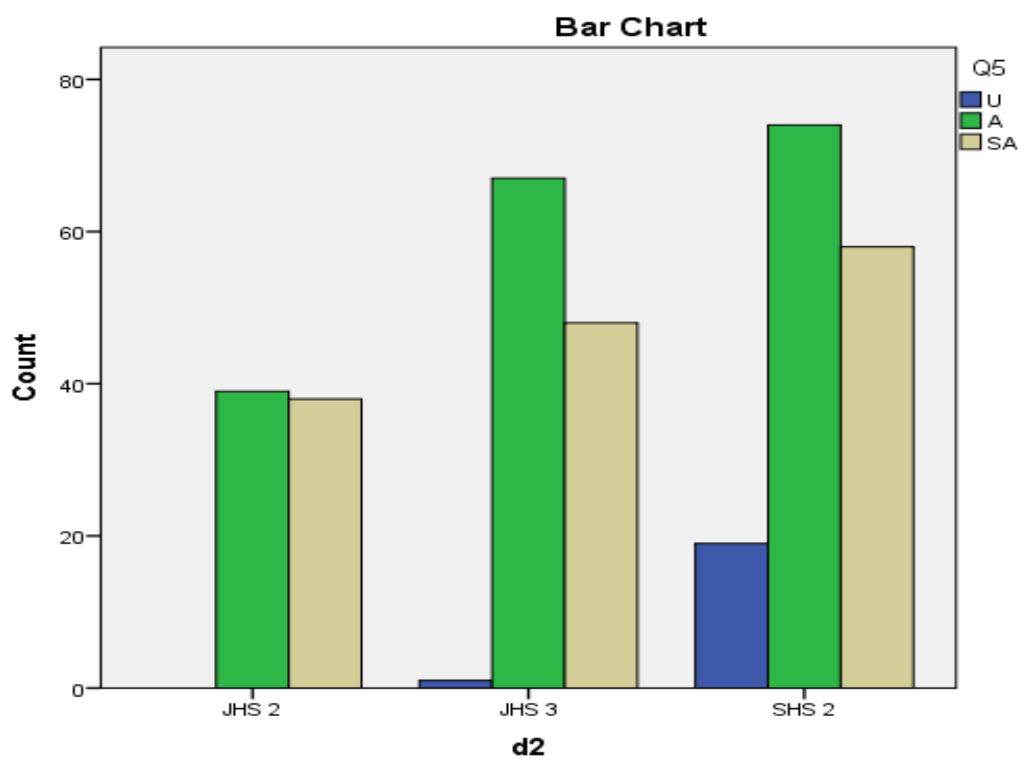

Table 10: Chi-Square Tests for Questionnaire Item 5

\begin{tabular}{|l|r|r|r|}
\hline & Value & df & Asymp. Sig. (2-sided) \\
\hline Pearson Chi-Square & $23.750^{\mathrm{a}}$ & 4 & .000 \\
Likelihood Ratio & 27.944 & 4 & .000 \\
Linear-by-Linear Association & 8.936 & 1 & .003 \\
N of Valid Cases & 344 & & \\
\hline
\end{tabular}

a 1 cells $(11.1 \%)$ have expected count less than 5 . The minimum expected count is 4.48 .

Table 11: Summary of Students' Responses to Questionnaire Item 5

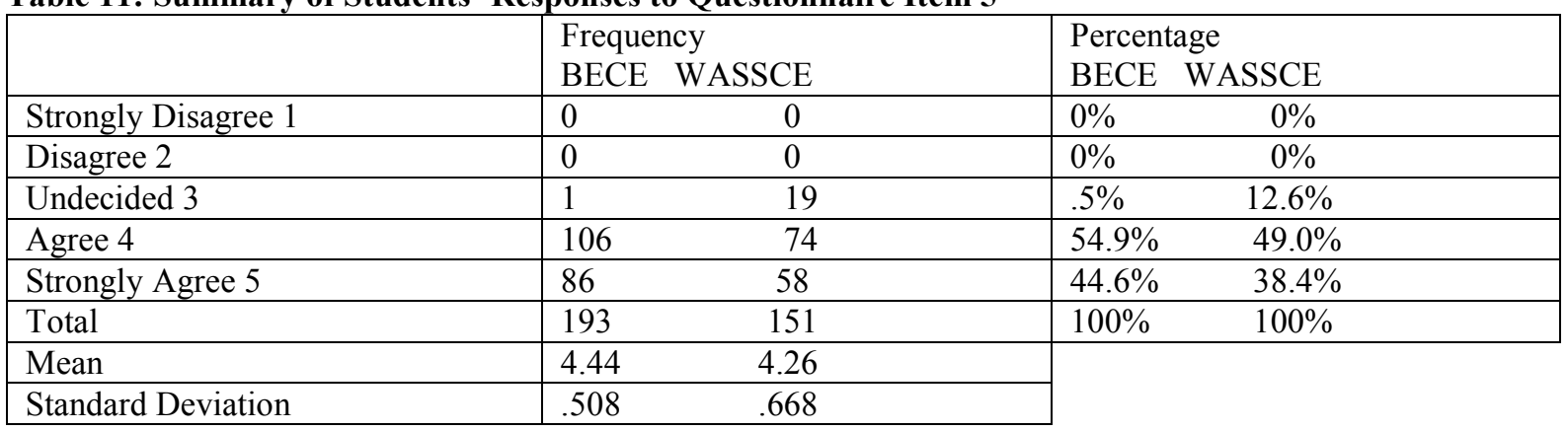




\subsubsection{Skipping Language Areas that are not Examined in the BECE/WASSCE}

It is said that when there is a mismatch between the stated goals of the curriculum and the focus of examination, teachers and students abandon curriculum goals in favour of examination (Bailey, 1996). This section analyses the views of students on whether or not their teachers should skip language areas or skills that are not covered in the BECE/WASSCE. Table 12 and Fig 4 below show the summary of students' responses to the questionnaire item 6 (Our English teachers should skip language areas that are not examined in the BECE/WASSCE). Only 1 out of the 344 students disagreed with the statement while 19 were undecided. 135 and 189 agreed and strongly agreed respectively with the statement. This means that the students agreed that their teachers should skip language areas or skills that are not examined in the BECE/WASSCE. The results were further subjected to Chi-Square test (as shown in Table 13) to find out whether the null hypothesis is true. The Chi-Square value of 9.019 ${ }^{\mathrm{a}}$ and the $d f$ of 6 means that the null hypothesis is true in this case. Table 14 below shows the comparison of the results between the BECE candidates and the WASSCE candidates. The WASSCE candidates, with the mean and standard deviation of $\mathbf{4 . 5 2}$ and $\mathbf{. 5 6 4}$ respectively, expressed a stronger desire to skip language areas that are not examined than the BECE candidates with the mean and standard deviation of $\mathbf{4 . 4 6}$ and $\mathbf{. 6 5 3}$ respectively.

Table 12: Our English teachers should skip language areas that are not examined in the BECE/WASSCE.

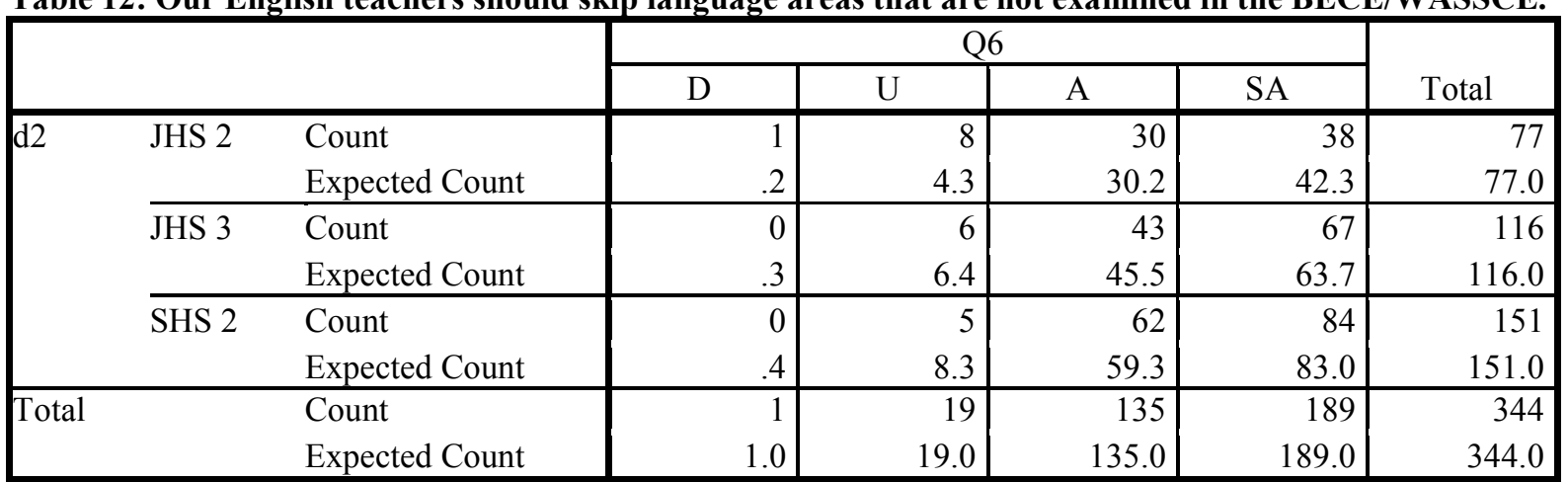

Fig 4: Our English teachers should skip language areas that are not examined in the BECE/WASSCE.

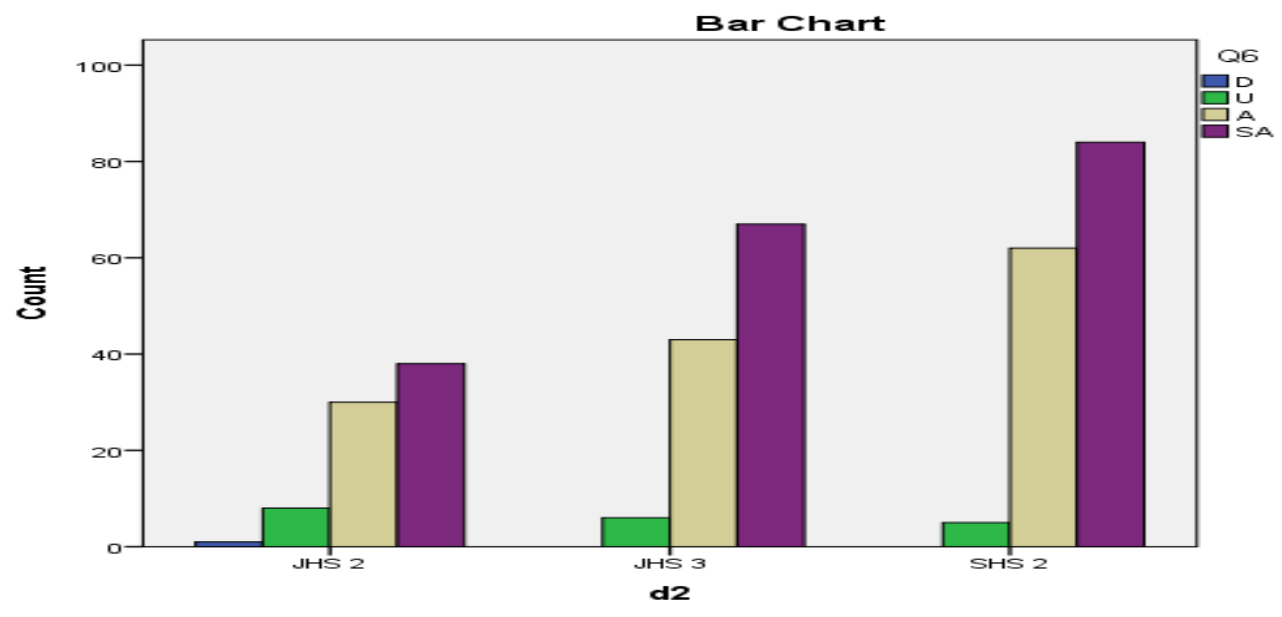

Table 13: Chi-Square Tests for Questionnaire Item 6

\begin{tabular}{|l|r|r|r|}
\hline & Value & df & Asymp. Sig. (2-sided) \\
\hline Pearson Chi-Square & $9.019^{\mathrm{a}}$ & 6 & .172 \\
Likelihood Ratio & 8.100 & 6 & .231 \\
Linear-by-Linear Association & 2.748 & 1 & .097 \\
N of Valid Cases & 344 & & \\
\hline
\end{tabular}

a. 4 cells $(33.3 \%)$ have expected count less than 5 . The minimum expected count is .22 . 
Table 14: Summary of Students' Responses to Questionnaire Item 6

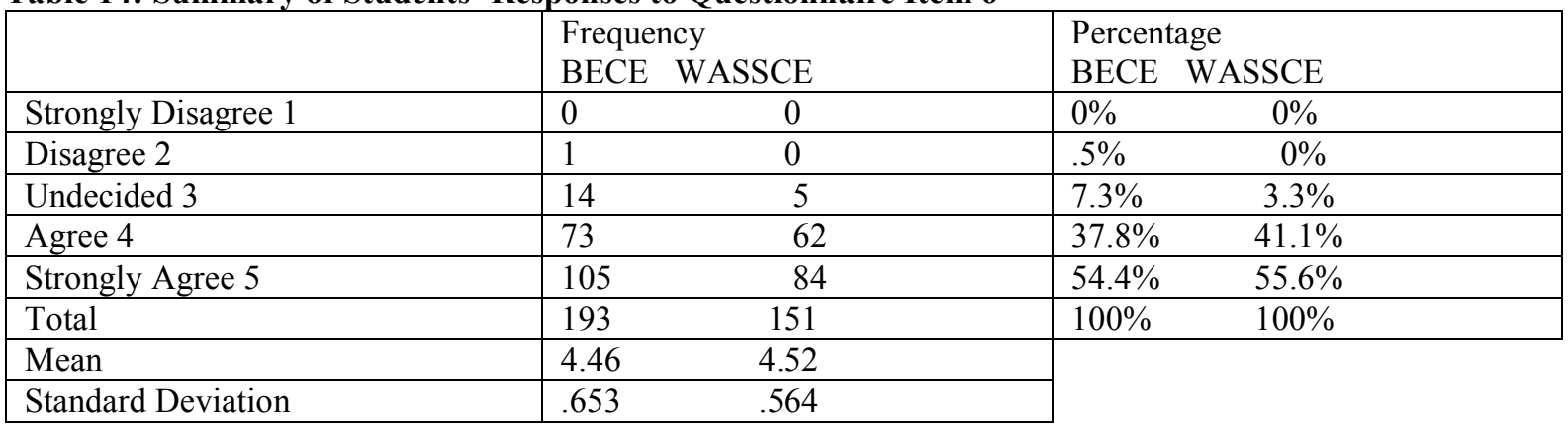

\subsubsection{Applying Classroom Learning to Practical Problems}

According to Wrenn and Wrenn, (2009), educators desire their students not only to learn theory and understand why theories are important but also to learn how to apply what is learnt in the classroom to practical problems. This section reports on views of students on whether their teachers set questions that demand application of what is learnt in the classroom to practical problems or questions that would only prepare the students to perform well in the BECE/WASSCE. Table 15 and Fig 5 show the analysis of the questionnaire item 7 (Our English teachers always set questions that ask us to apply what we learn to practical problems). The results show that teachers do not ask students to apply what they learn to practical problems; rather teaching, learning, and testing are directed towards the BECE/WASSCE. 72 of the students were uncertain while 112 and 160 strongly disagreed and disagreed respectively with the statement. Table 16 also shows the Chi-Square test results of students' views on whether or not teachers set questions that demand application of what they learn to practical problems. The ChiSquare value of $12.577^{\mathrm{a}}$ and the $d f$ of $\mathbf{4}$ show that the null hypothesis is true in this case. It can therefore be concluded that teachers do not set questions that demand application of what is learnt in the classroom to practical problems. However, the mean result of $\mathbf{1 . 9 7}$ and $\mathbf{1 . 7 7}$ for BECE and WASSCE respectively (as shown in Table 17) indicates that BECE questions are closer to solving practical problems than the WASSCE in the study.

Table 15: Our English teachers always set questions that ask us to apply what we learn to practical problems. Crosstab

\begin{tabular}{|c|c|c|c|c|c|c|}
\hline & & & & Q7 & & \\
\hline & & & $\mathrm{SD}$ & $\mathrm{D}$ & $\mathrm{U}$ & Total \\
\hline $\mathrm{d} 2$ & JHS 2 & Count & 14 & 45 & 18 & 77 \\
\hline & & Expected Count & 25.1 & 35.8 & 16.1 & 77.0 \\
\hline & JHS 3 & Count & 39 & 48 & 29 & 116 \\
\hline & & Expected Count & 37.8 & 54.0 & 24.3 & 116.0 \\
\hline & SHS 2 & Count & 59 & 67 & 25 & 151 \\
\hline & & Expected Count & 49.2 & 70.2 & 31.6 & 151.0 \\
\hline Total & & Count & 112 & 160 & 72 & 344 \\
\hline & & Expected Count & 112.0 & 160.0 & 72.0 & 344.0 \\
\hline
\end{tabular}


Fig 5: Our English teachers always set questions that ask us to apply what we learn to practical problems.

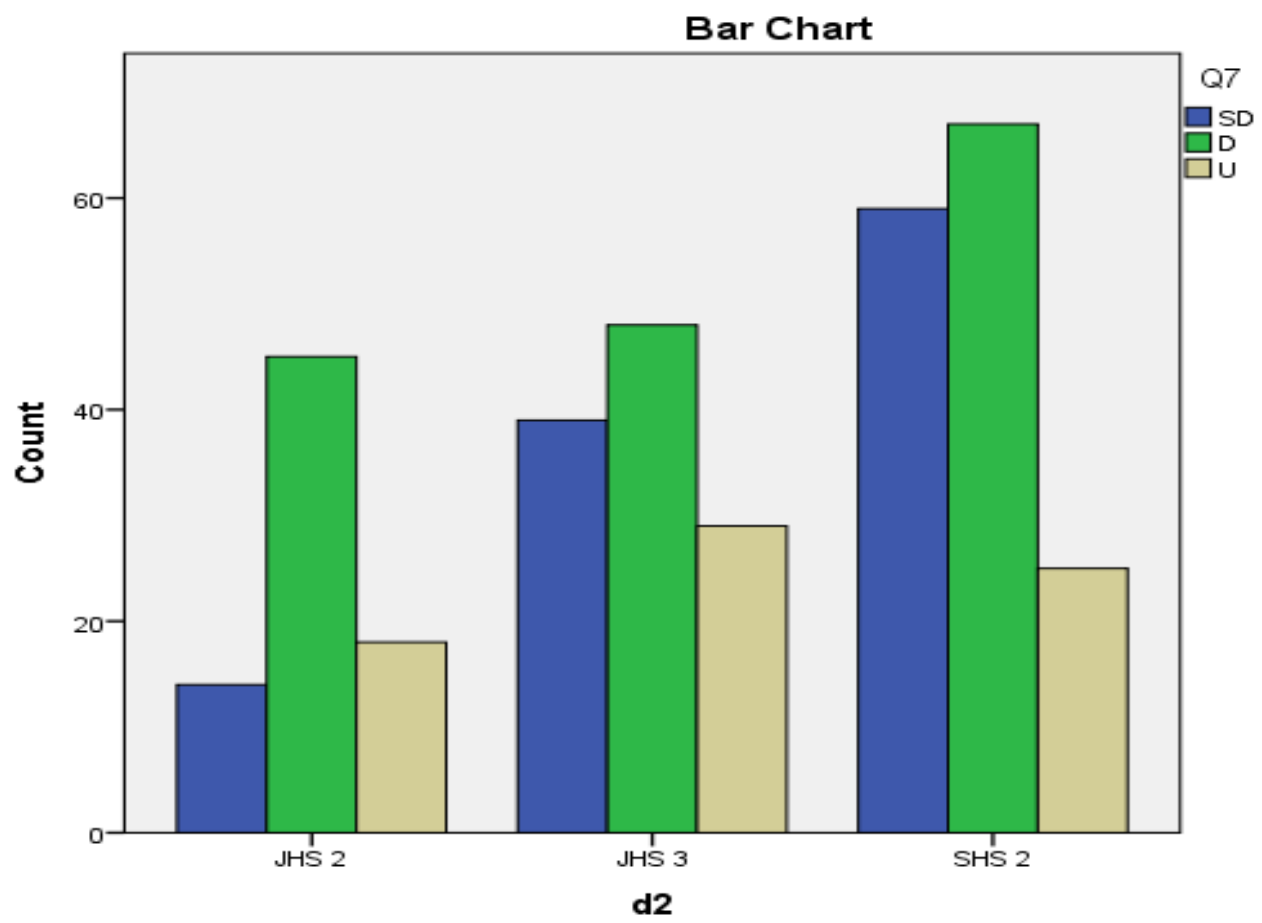

Table 16: Chi-Square Tests for Questionnaire Item 7

\begin{tabular}{|l|r|r|r|}
\hline & Value & df & Asymp. Sig. (2-sided) \\
\hline Pearson Chi-Square & $12.577^{\mathrm{a}}$ & 4 & .014 \\
Likelihood Ratio & 13.290 & 4 & .010 \\
Linear-by-Linear Association & 7.792 & 1 & .005 \\
N of Valid Cases & 344 & & \\
\hline
\end{tabular}

a. 0 cells $(.0 \%)$ have expected count less than 5 . The minimum expected count is 16.12 .

Table 17: Summary of Students' Responses to Questionnaire Item 7

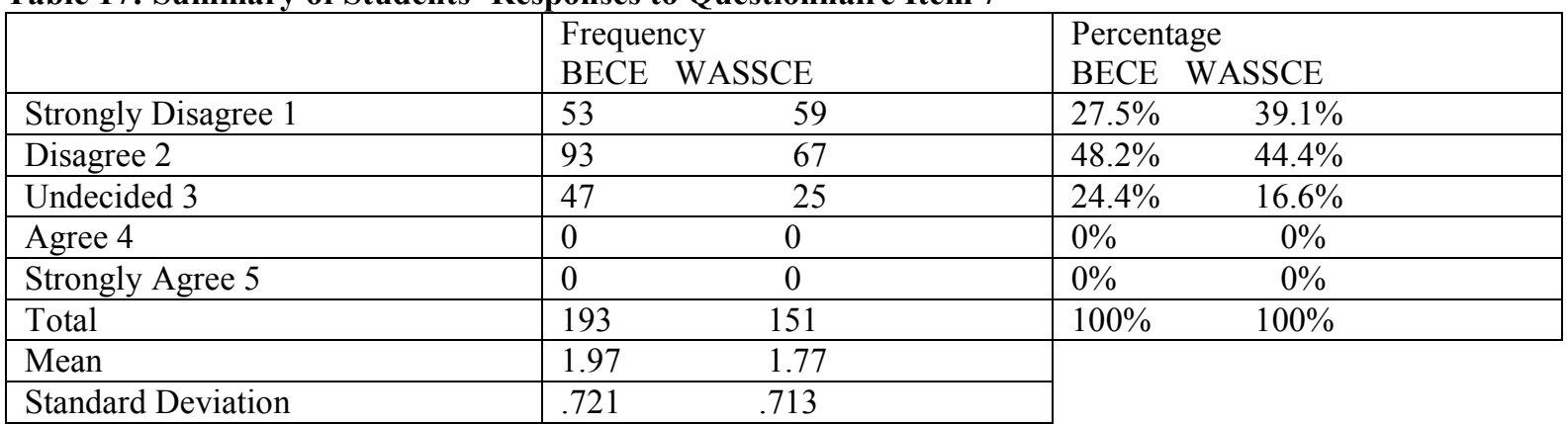

\subsubsection{The Use of Past Exam Papers in Teaching and Learning of English}

The importance of past exam papers in effective revision for exams cannot be overemphasised. Ideally students are expected to consult past exam papers after they have successfully gone through the syllabus. However, high stakes tests have the tendency of putting pressure on students to concentrate on solving past exam papers, rather than concentrating on completing the syllabus. This section analyses views of students on the teachers' use of past exam papers in teaching. Table 18 and Fig 6 show the analysis of the questionnaire item 9 (Our teachers should use BECE/WASSCE past questions in their teaching). Only 1 of the students disagreed with the statement while 3 were undecided. 121 and 219 agreed and strongly agreed respectively with the statement. The results show that the students wanted their teachers to teach with past exam papers instead of syllabus. This implies that concentrating on completing the syllabus would be considered as a waste of students' time. The study further subjected the views of the students analysed in Table 18 and Fig 6 to Chi-Square test to find out whether the null hypothesis is true in this case. The Chi-Square results (as shown in Table 19) with the value of $\mathbf{1 4 . 7 3 8}^{\mathbf{a}}$ and $d f$ of 6 indicate that the null hypothesis is true. The findings show that both JHS and SHS candidates wanted their 
teachers to teach with past questions. However, the mean and the standard deviation of $\mathbf{4 . 6 7}$ and $\mathbf{. 5 2 4}$ respectively for BECE are higher than that of the WASSCE with the mean and the standard deviation of 4.56 and .511 respectively, as indicated in Table 20 below. What this means is that the JHS students expressed a stronger desire for their teachers to teach with past questions than their SHS counterparts.

Table 18: Our teachers should use BECE/WASSCE past questions in their teaching.

\section{Crosstab}

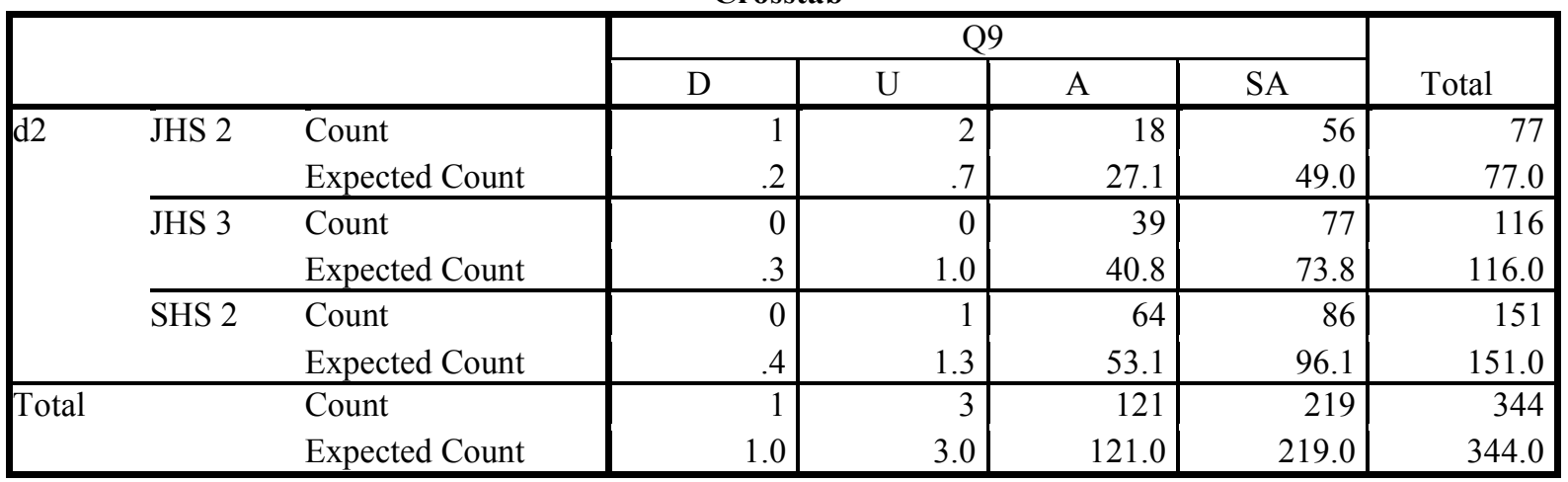

Fig 6: Our teachers should use BECE/WASSCE past questions in their teaching.

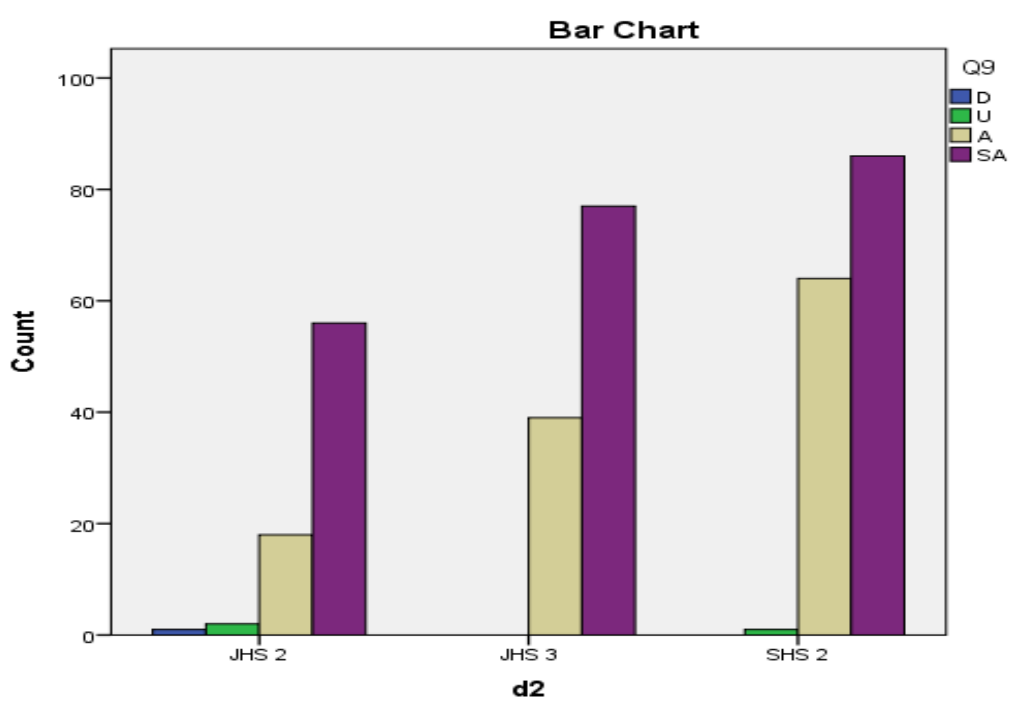

Table 19: Chi-Square Tests for Questionnaire Item 9

\begin{tabular}{|l|r|r|r|}
\hline & Value & df & Asymp. Sig. (2-sided) \\
\hline Pearson Chi-Square & $14.738^{\mathrm{a}}$ & 6 & .022 \\
Likelihood Ratio & 14.632 & 6 & .023 \\
Linear-by-Linear Association & 2.959 & 1 & .085 \\
N of Valid Cases & 344 & & \\
\hline
\end{tabular}

a. 6 cells $(50.0 \%)$ have expected count less than 5 . The minimum expected count is .22 .

Table 20: Summary of Students' Responses to Questionnaire Item 9

\begin{tabular}{|c|c|c|c|c|}
\hline & $\begin{array}{l}\text { Frequ } \\
\text { BEC }\end{array}$ & SCE & $\begin{array}{l}\text { Percen } \\
\text { BECE }\end{array}$ & SSCE \\
\hline Strongly Disagree 1 & 0 & 0 & $0 \%$ & $0 \%$ \\
\hline Disagree 2 & 1 & 0 & $.5 \%$ & $0 \%$ \\
\hline Undecided 3 & 2 & 1 & $1.0 \%$ & $.7 \%$ \\
\hline Agree 4 & 57 & 64 & $29.5 \%$ & $42.4 \%$ \\
\hline Strongly Agree 5 & 133 & 86 & $68.9 \%$ & $57.0 \%$ \\
\hline Total & 193 & 151 & $100 \%$ & $100 \%$ \\
\hline Mean & 4.67 & 4.56 & & \\
\hline Standard Deviation & .524 & .511 & & \\
\hline
\end{tabular}




\subsubsection{Students' Preference for Teachers who are WAEC Examiners}

Being an examiner and teacher affords one a deeper understanding of what is required of their students in the examination room. However, being an examiner would not necessarily make one a good teacher. It is said that a good teacher is the one that instils love of learning in their students and not the one who prepares students just to pass an examination. This section reports on the views of students on their preference for teachers who are examiners. The section analyses students' responses to the questionnaire item 11 (I would like my teacher to be an examiner for $W A E C$ ). As indicated in Table 21 and Fig 7, only 1 student disagreed with the statement while 7 were undecided. 101 and 235 agreed and strongly agreed respectively with the statement. This means that the students wanted their teachers to be WAEC examiners. The results were further subjected to Chi-Square test as shown in Table 22. Chi-Square value of $\mathbf{6 . 7 6 3}^{\mathbf{a}}$ and $d f$ of $\mathbf{6}$ mean that the null hypothesis is true. Table 23 also shows the mean and the standard deviation application to the results. The results show the mean and standard deviation of 4.67 and .524 respectively for BECE and 4.64 and $\mathbf{5 4 6}$ respectively for WASSCE. What this means is that the JHS students expressed a stronger preference for teachers who are examiners than their SHS counterparts.

Table 21: I would like my teacher to be an examiner for WAEC

Crosstab

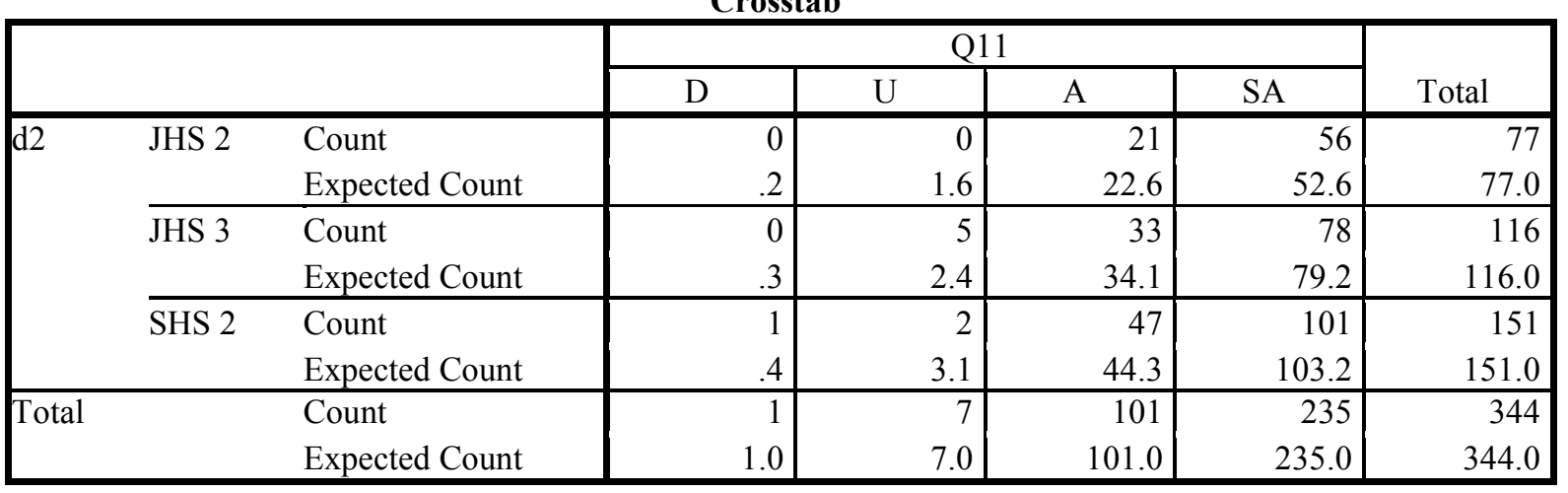

Fig 7: I would like my teacher to be an examiner for WAEC

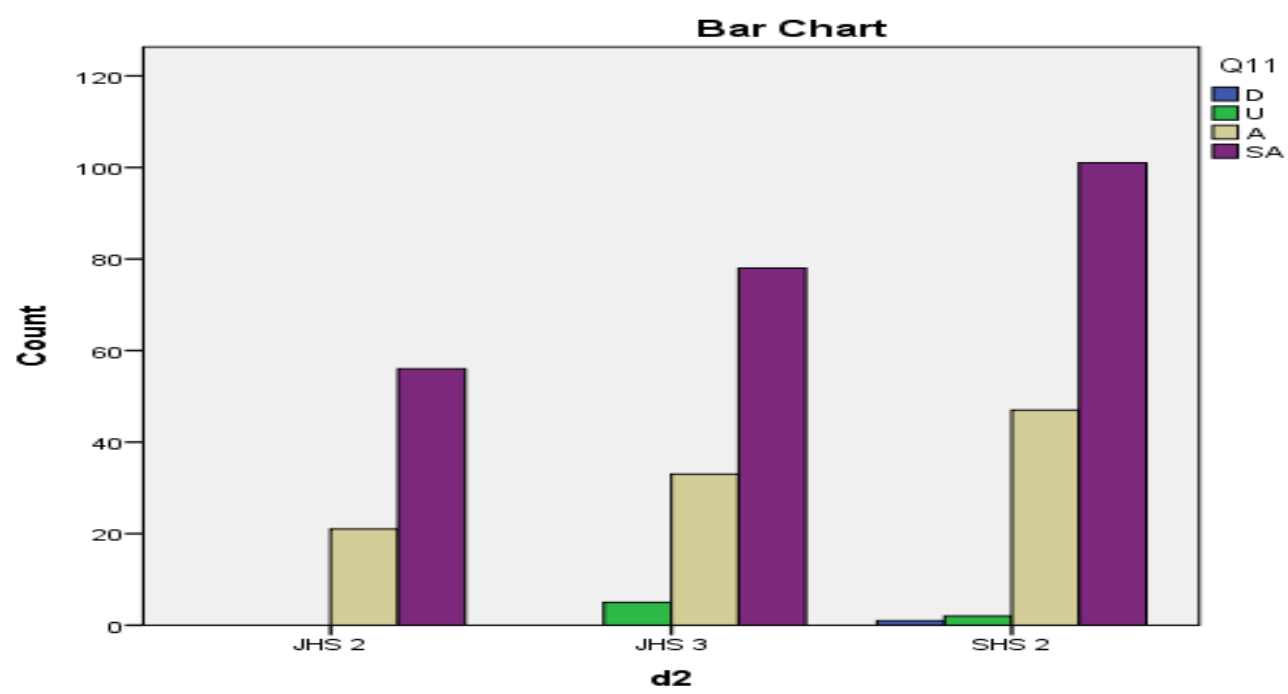

Table 22: Chi-Square Tests for Questionnaire Item 11

\begin{tabular}{|l|r|r|r|}
\hline & Value & df & Asymp. Sig. (2-sided) \\
\hline Pearson Chi-Square & $6.763^{\mathrm{a}}$ & 6 & .343 \\
Likelihood Ratio & 8.022 & 6 & .236 \\
Linear-by-Linear Association & .962 & 1 & .327 \\
N of Valid Cases & 344 & & \\
\hline
\end{tabular}

a. 6 cells $(50.0 \%)$ have expected count less than 5 . The minimum expected count is .22 . 
Table 23: Summary of Students' Responses to Questionnaire Item 11

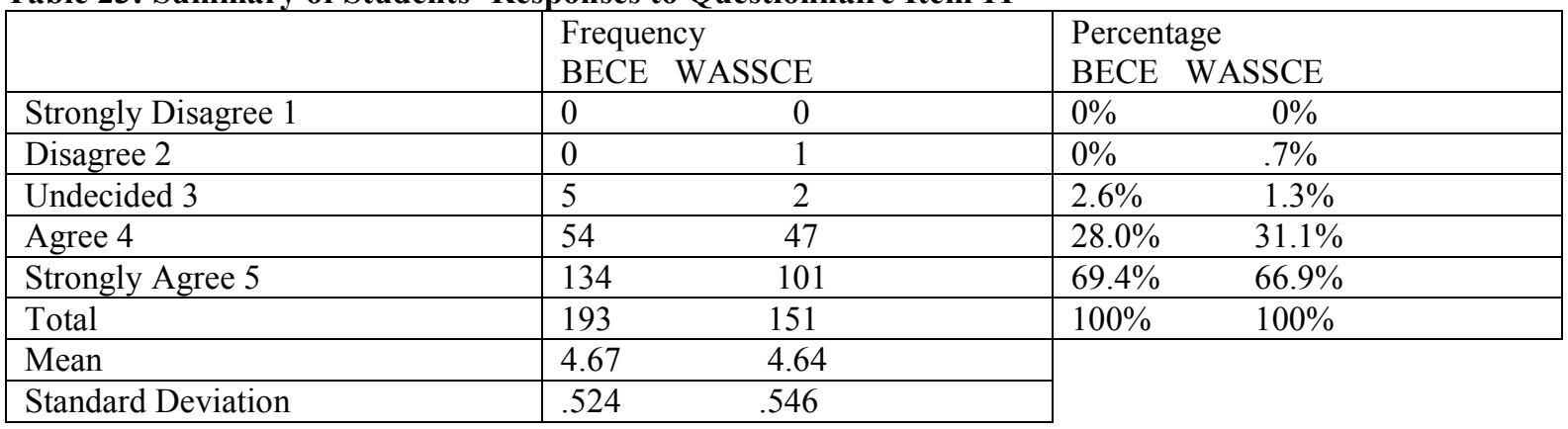

\subsubsection{Students' Desire to be Coached to Answer BECE/WASSCE Questions}

It was found out in 1.8 .7 above that the students in this study wanted their teachers to be WAEC examiners. Perhaps the students wanted their teachers to be WAEC examiners so that they can be given special instructions on how to answer examination questions appropriately. This section analyses the views of students on their desire to be coached to answer BECE/WASSCE questions. The section analyses the students' responses to the questionnaire item 12 (I think that our teachers should coach us to answer BECE/WASSCE questions). As shown in Table 24 and Fig 8, only 3 out of the 344 students disagreed with the statement while 5 were undecided. 84 and 252 agreed and strongly agreed respectively with the statement. This means that the students wanted their teachers to coach them to answer BECE/WASSCE questions. Table 25 also shows the Chi-Square test of the results shown in Table 24 and Fig 8 to find out whether the null hypothesis is true. The Chi-Square value of $\mathbf{1 2 . 0 0 9}^{\mathbf{a}}$ and the $d f$ of $\mathbf{6}$ mean that there is no significant difference between the expected frequencies and the observed frequencies. This means that the null hypothesis is true. Table 26 shows the comparison between the views of BECE candidates and that of WASSCE candidates. The standard deviation of $\mathbf{. 4 4 7}$ and $\mathbf{. 6 4 0}$ for BECE and WASSCE respectively suggests that the views of the BECE candidates did not significantly differ, as compared to that of the WASSCE candidates. Again, the mean of $\mathbf{4 . 7 3}$ and $\mathbf{4 . 6 7}$ for BECE and WASSCE respectively suggests that the BECE candidates expressed a stronger desire to be coached to answer BECE questions than the WASSCE candidates.

Table 24: I think that our teachers should coach us to answer BECE/WASSCE questions

\begin{tabular}{|c|c|c|c|c|c|c|c|}
\hline & & & \multicolumn{4}{|c|}{ Q12 } & \multirow[b]{2}{*}{ Total } \\
\hline & & & $\mathrm{D}$ & $\mathrm{U}$ & A & SA & \\
\hline \multirow[t]{6}{*}{$\mathrm{d} 2$} & JHS 2 & Count & 0 & 0 & 22 & 55 & 77 \\
\hline & & Expected Count & .7 & 1.1 & 18.8 & 56.4 & 77.0 \\
\hline & JHS 3 & Count & 0 & 0 & 31 & 85 & 116 \\
\hline & & Expected Count & 1.0 & 1.7 & 28.3 & 85.0 & 116.0 \\
\hline & SHS 2 & Count & 3 & 5 & 31 & 112 & 151 \\
\hline & & Expected Count & 1.3 & 2.2 & 36.9 & 110.6 & 151.0 \\
\hline \multirow[t]{2}{*}{ Total } & & Count & 3 & 5 & 84 & 252 & 344 \\
\hline & & Expected Count & 3.0 & 5.0 & 84.0 & 252.0 & 344.0 \\
\hline
\end{tabular}

Fig 8: I think that our teachers should coach us to answer BECE/WASSCE questions

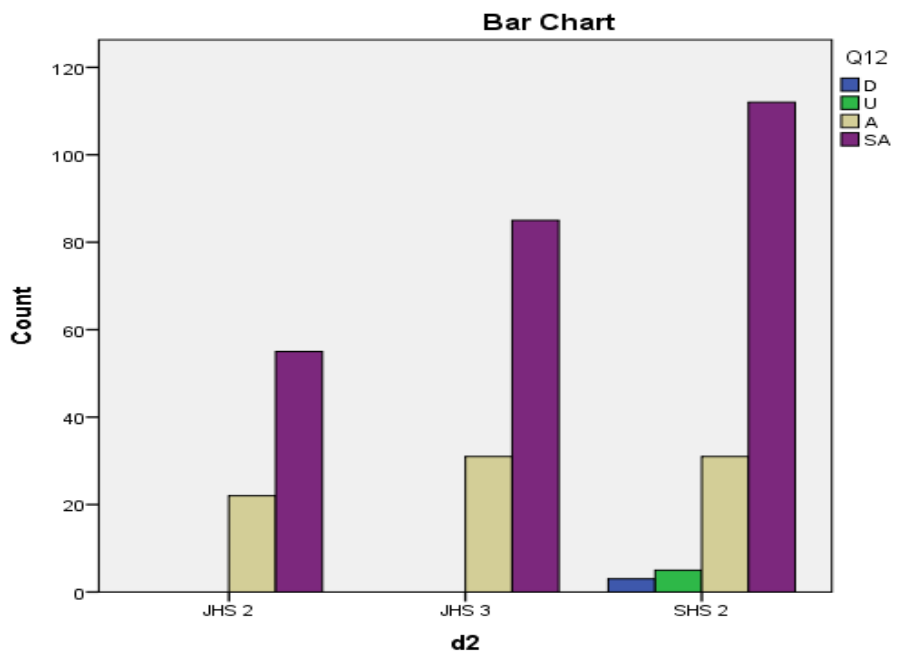


Table 25: Chi-Square Tests for Questionnaire Item 12

\begin{tabular}{|l|r|r|r|}
\hline & Value & df & Asymp. Sig. (2-sided) \\
\hline Pearson Chi-Square & $12.009^{\mathrm{a}}$ & 6 & .062 \\
Likelihood Ratio & 14.976 & 6 & .020 \\
Linear-by-Linear Association & .551 & 1 & .458 \\
N of Valid Cases & 344 & & \\
\hline
\end{tabular}

a. 6 cells $(50.0 \%)$ have expected count less than 5 . The minimum expected count is .67 .

Table 26: Summary of Students' Responses to Questionnaire Item 12

\begin{tabular}{|c|c|c|c|c|}
\hline & \multicolumn{2}{|c|}{ Frequency } & \multicolumn{2}{|c|}{ Percentage } \\
\hline & \multicolumn{2}{|c|}{ BECE WASSCE } & \multicolumn{2}{|c|}{ BECE WASSCE } \\
\hline Strongly Disagree 1 & 0 & 0 & $0 \%$ & $0 \%$ \\
\hline Disagree 2 & 0 & 3 & $0 \%$ & $2 \%$ \\
\hline Undecided 3 & 0 & 5 & $0 \%$ & $3.3 \%$ \\
\hline Agree 4 & 53 & 31 & $27.5 \%$ & $20.5 \%$ \\
\hline Strongly Agree 5 & 140 & 112 & $72.5 \%$ & $74.2 \%$ \\
\hline Total & 193 & 151 & $100 \%$ & $100 \%$ \\
\hline Mean & 4.73 & 4.67 & & \\
\hline Standard Deviation & .447 & .640 & & \\
\hline
\end{tabular}

\subsubsection{Students' Anxiety about the BECE/WASSCE}

According to Spratt, (2005) examinations generate an atmosphere of high anxiety and fear of test results among both teachers and students. It is this examination anxiety that sometimes leads to negative washback effect. This section analyses the views of students on how the BECE/WASSCE creates anxiety in them. The section analyses the students' responses to the questionnaire item 13 ( $I$ am always anxious about the BECE/WASSCE). As shown in Table 27 and Fig 9, only 2 and 9 students strongly disagreed and disagreed respectively with the statement while 15 were undecided. 169 and 149 agreed and strongly agreed respectively with the statement. This implies that the students were always anxious about the BECE/WASSCE. Table 28 also shows the Chi-Square test analysis of the results presented in Table 41 and Fig 10. The Chi-Square value of $16.744^{\mathrm{a}}$ and the $d f$ of 8 means that the null hypothesis is true in this case. The mean and the standard deviation results are shown in Table 29 below. The mean of 4.40 and 4.21 for BECE and WASSCE respectively shows that the BECE creates a higher level of anxiety in students than the WASSCE. Again, the standard deviation of $\mathbf{. 5 7 0}$ and $\mathbf{. 8 8 4}$ for BECE and WASSCE respectively implies that the views of WASSCE candidates differed more significantly than that of the BECE candidates.

Table 27: I am always anxious about the BECE/WASSCE

\section{Crosstab}

\begin{tabular}{|c|c|c|c|c|c|c|c|c|}
\hline & \multicolumn{5}{|c|}{ Q13 } & \multirow[b]{2}{*}{ Total } \\
\hline & & & $\mathrm{SD}$ & $\mathrm{D}$ & $\mathrm{U}$ & A & SA & \\
\hline \multirow[t]{6}{*}{$\mathrm{d} 2$} & \multirow[t]{2}{*}{ JHS 2} & Count & 0 & 0 & 0 & 43 & 34 & 77 \\
\hline & & Expected Count & .4 & 2.0 & 3.4 & 37.8 & 33.4 & 77.0 \\
\hline & \multirow[t]{2}{*}{ JHS 3} & Count & 0 & 1 & 5 & 59 & 51 & 116 \\
\hline & & Expected Count & .7 & 3.0 & 5.1 & 57.0 & 50.2 & 116.0 \\
\hline & \multirow[t]{2}{*}{ SHS 2} & Count & 2 & 8 & 10 & 67 & 64 & 151 \\
\hline & & Expected Count & .9 & 4.0 & 6.6 & 74.2 & 65.4 & 151.0 \\
\hline \multirow[t]{2}{*}{ Total } & & Count & 2 & 9 & 15 & 169 & 149 & 344 \\
\hline & & Expected Count & 2.0 & 9.0 & 15.0 & 169.0 & 149.0 & 344.0 \\
\hline
\end{tabular}


Fig 9: I am always anxious about the BECE/WASSCE

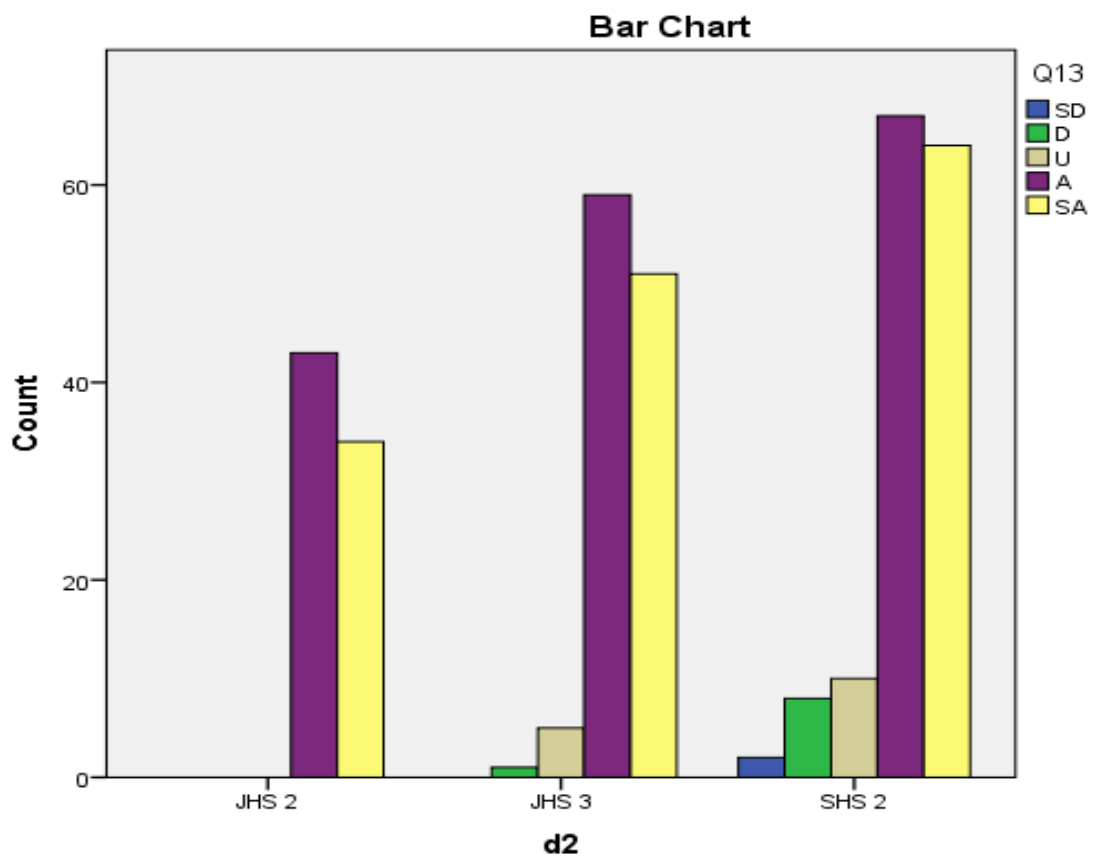

Table 28: Chi-Square Tests for Questionnaire Item 13

\begin{tabular}{|l|r|r|r|}
\hline & Value & df & Asymp. Sig. (2-sided) \\
\hline Pearson Chi-Square & $16.744^{\mathrm{a}}$ & 8 & .033 \\
Likelihood Ratio & 22.125 & 8 & .005 \\
Linear-by-Linear Association & 5.826 & 1 & .016 \\
N of Valid Cases & 344 & & \\
\hline
\end{tabular}

a. 7 cells $(46.7 \%)$ have expected count less than 5 . The minimum expected count is .45 .

Table29: Summary of Students' Responses to Questionnaire Item 13

\begin{tabular}{|l|lc|lc|}
\hline & \multicolumn{3}{|l|}{ Frequency } & \multicolumn{2}{l|}{ Percentage } \\
& BECE & WASSCE & BECE & WASSCE \\
\hline Strongly Disagree 1 & 0 & 2 & $0 \%$ & $1.3 \%$ \\
\hline Disagree 2 & 1 & 8 & $.5 \%$ & $5.3 \%$ \\
\hline Undecided 3 & 5 & 10 & $2.6 \%$ & $6.6 \%$ \\
\hline Agree 4 & 102 & 67 & $52.8 \%$ & $44.4 \%$ \\
\hline Strongly Agree 5 & 85 & 64 & $44.0 \%$ & $42.4 \%$ \\
\hline Total & 193 & 151 & $100 \%$ & $100 \%$ \\
\hline Mean & 4.40 & 4.21 & & \\
\cline { 1 - 3 } Standard Deviation & .570 & .884 & & \\
\cline { 1 - 3 } &
\end{tabular}

\section{Results from Interviews}

Similar results on students' attitudes towards language skills/areas that are not covered in the final examinations were obtained from the students' responses to interviews as shown in Table 30 below. With the exception of Interviewees $6,8,9$, and 11 who seemed to be saying that the WASSCE had positive effect on their learning, the rest $(87 \%)$ of the Interviewees indicated that the WASSCE influenced them negatively. A majority $(87 \%)$ of the interviewees seemed to be indicating that the WASSCE did not adequately test skills that could prepare them for life, and that the examination was too theoretical. The students therefore tended to concentrate on examinable areas by relying heavily on past questions in their studies. For instance, Interviewee 24 said that his learning of English was geared towards passing examination. Many of the students therefore learnt with question-and-answer booklets. 
Table 30: Students' Interview Responses on how the WASSCE Influences the way they Learn English

\begin{tabular}{|c|c|}
\hline Question & $\begin{array}{l}\text { Summary of Responses } \\
\text { (Interviewees } 1 \text { to } 10 \text { were from St. Augustine's College, } 11 \text { to } 20 \text { were from Adisadel } \\
\text { College, } 21 \text { to } 30 \text { were from Aggrey Memorial SHS). }\end{array}$ \\
\hline $\begin{array}{l}\text { 2. How does the } \\
\text { WASSCE } \\
\text { influence the } \\
\text { way you learn } \\
\text { English } \\
\text { language? }\end{array}$ & 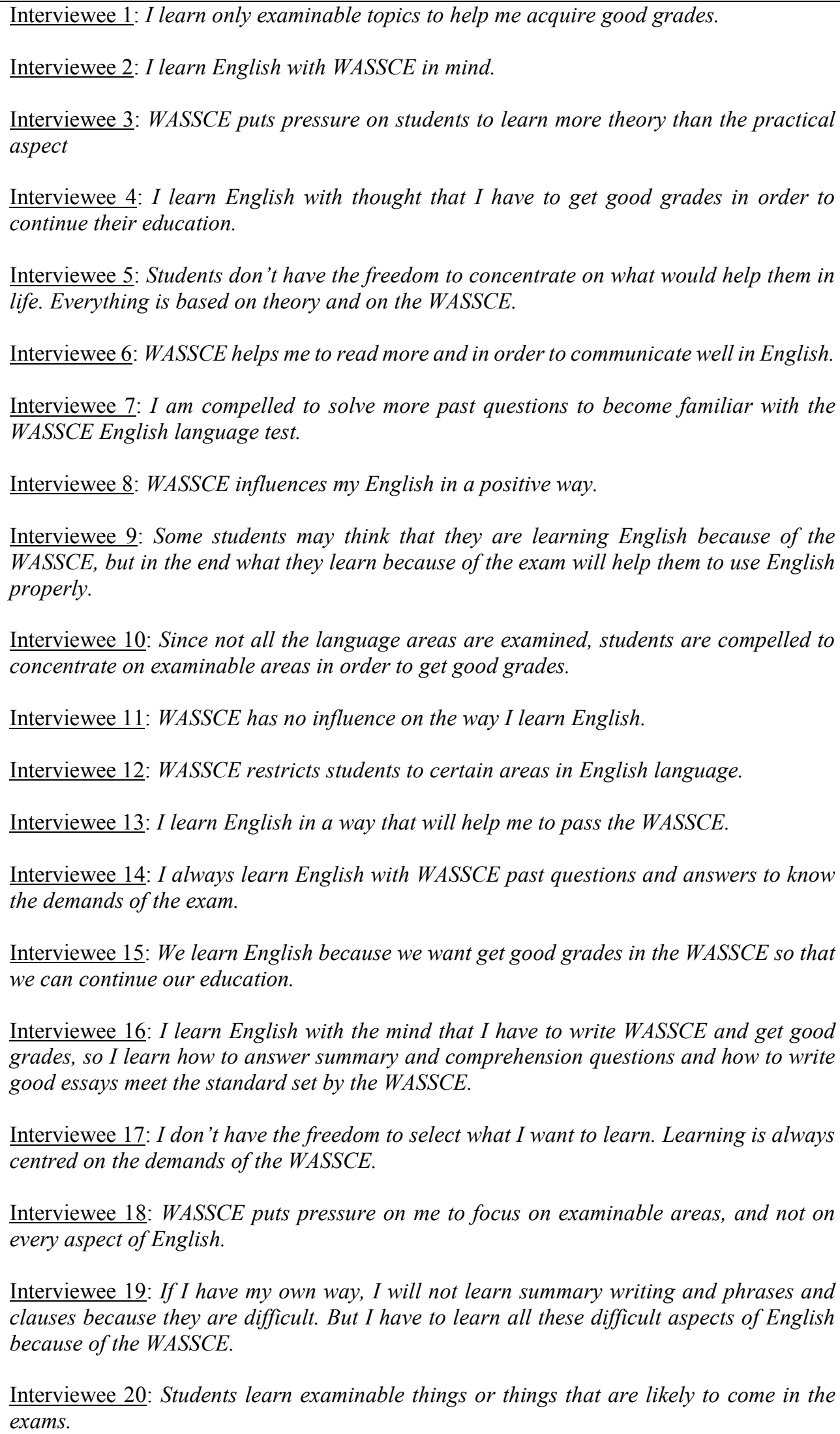 \\
\hline
\end{tabular}


Interviewee 21: WASSCE compels me to learn English and solve past questions.

Interviewee 22: I think we learn English because of the WASSCE. It is the examination that will measure our level of competence.

Interviewee 23: I always learn what will help me to perform well in the WASSCE.

Interviewee 24: My learning of English is geared towards passing examination. Many of us students therefore learn with question-and-answer booklets.

Interviewee 25: Our main aim of learning English is getting good grades in the WASSCE so that we can gain admission into the university.

Interviewee 26: I concentrate on areas that are examined in the WASSCE. I want my English teacher to also do that because we don't have much time.

Interviewee 27: I am always anxious about the WASSCE, so I concentrate on examinable areas. I don't like teachers who waste students' time on 'non-sylla'.

Interviewee 28: I learn by always solving past questions. I use past questions to guide my learning.

Interviewee 29: WASSCE restricts me from reading wide outside the syllabus.

Interviewee 30: WASSCE does not allow students to learn English for life. Even the oral English aspect does not allow students to speak the language, we only listen and shade.

\subsubsection{Conclusion}

The study made use of the data gathered through questionnaires and interviews to provide answers to the question: What are the attitudes of learners towards language skills or areas that are not covered in the BECE/WASSCE? The areas explored were the following:

$>$ The language areas students expected their teachers to focus on

$>$ How the BECE/WASSCE influenced how students learn English

$>$ Language skills or areas that attracted students' attention

$>$ The use of past exam papers in teaching and learning of English

$>$ Students' preference for teachers who were WAEC examiners

$>$ Students' desire to be coached to answer BECE/WASSCE questions

$>$ Students' anxiety about the BECE/WASSCE

The analysis of the students' questionnaire and interview showed that both JHS students and SHS students wanted their teachers to concentrate on language areas that would only make them perform well in their final examinations. However, the JHS students and BECE candidates tended to put more pressure on their teachers to concentrate on examinable areas than the WASSCE candidates. This means that the BECE exerted a greater negative washback effect on the students than the WASSCE. This might be attributed to the criterion used in the selection of JHS leavers into SHS. It is not only the grades of the candidates that are considered for selection into senior high schools. Selection of JHS leavers into SHS is also based on the raw scores of candidates. Grade 1 is between $80 \%$ and $100 \%$. Two candidates, $A$ and $B$ with the average scores of $82 \%$ and $98 \%$ respectively have both got grade 1 , but the candidate $B$ could be considered first for a grade $A$ school or for their first choice school. This makes the competition in the JHS keener than that of the SHS.

The study again revealed that although both the BECE and the WASSCE created some anxiety in students, the BECE created a higher level of anxiety in students than the WASSCE. This is because, unlike the selection into second cycle institutions which is based on candidates' raw scores, the selection into tertiary institutions and programmes is only based on students' grades. For this reason:

i. The BECE candidates tended to put more pressure on their teachers to concentrate on examinable areas than the WASSCE candidates.

ii. The BECE candidates focused their attention on the examinable areas more than the WASSCE candidates.

iii. The JHS students expressed a stronger desire for their teachers to teach with past questions than their SHS counterparts.

iv. The JHS students expressed a stronger preference for teachers who were examiners than their SHS 
counterparts.

v. The BECE candidates expressed a stronger desire to be coached to answer BECE questions than the WASSCE candidates.

In effect, the BECE tended to exert a greater negative washback effect on the students than the WASSCE in the study. Although this comparison of washback effect of the BECE and the WASSCE English language test on JHS students and SHS students respectively was not the focus of the study, it became necessary because the present washback study considered the two high-stakes examinations. An examination of the related literature showed that many of the washback studies examined the impact of only one high-stakes examination on teaching and learning at a time. The current study is among the few washback studies that focus on two high-stakes examinations.

The findings revealed that both BECE and WASSCE English language tests exerted negative influence on the students' learning, and that very little attention was given to language areas or skills that were not covered in BECE and WASSCE. The BECE/WASSCE English language test had detrimental effects on students' communicative competence. This is because there was a mismatch between the content of the syllabus and the focus of the BECE/WASSCE English language test. The study again revealed that there was not much difference between the JHS students and the SHS students on how they learnt English. Both examinations influenced how students learnt English. This confirms the Alderson and Wall's washback hypotheses that a test will influence what and how learners learn.

In order to bring about a positive washback effect, WAEC should make every endeavour to assess students on all the language skills at all levels, namely: listening skills, reading skills, writing skills, and reading skills. Until this is done, teachers of English and their students will continue to concentrate on only examinable areas.

\section{References}

Agbeti, A. (2011). Influences of external assessment on teaching and learning in junior high school in Ghana. Doctor of Education Thesis, University of Sussex.

Alderson, J. C. (1986). Innovations in language testing. In M. Portal (Ed.), Innovations in language testing:Proceedings of the IUS/NFER conference (pp. 93-105). Windsor: NFER-Nelson.

Alderson, J. C. \& Hamp-Lyons, L. (1996) TOEFL preparation courses: a study of washback.Language Testing 13(3), 280-297

Alderson, J. C. \& Wall, D. (1993a). Does washback exist? Applied Linguistics, 14(2), 115-129.

Alderson, J. C. \& Wall, D. (1993b). Examining washback: Sri Lankan impact study. Language Testing. Vol.10, No.1, 41-69

Bachman, L. F. (1990). Fundamental considerations in language testing. Oxford: Oxford University Press

Bailey, K. M. (1996). Working for washback: A review of the washback concept in language testing. Language Testing 13(3), 257-279.

Cheng, L. (1997). How does washback influence teaching? Implications for Hong Kong, Language and Education, 11(1), 38-54

Cheng, L. (1999). Changing assessment: washback on teacher perceptions and actions. Teaching and Teacher Education. 15, 253-271.

Elton, L. and Laurillard, D. (1979) Trends in student learning. Studies in higher education, 4, 87-102

Ghorbani, M. R. \& Neissari, M. (2015) Washback effect of the Iranian concours on senior high school students' EFL learning activities. Iranian Journal of Language Testing Vol. 5, No. 1, 2-28

Green, A. (2007). Washback to learning outcomes: a comparative study of IELTS preparation and university presessional language courses. Assessment in Education. 14 (1), 75-97.

Hayes, B. \& Read, J. (2004) IELTS test preparation in New Zealand: preparing students for the IELTS academic module, In L. Cheng, Y. Watanabe \& A. Curtis (Eds): Washback in language testing: research contexts and methods, 97-112, Mahwah, NJ: Lawrence Erlbaum Associates.

Hsiu-yu C. (2009). Stakes, needs and washback: An investigation of the English benchmark policy for graduation and EFL education at two technological universities in Taiwan. PhD thesis, National Taiwan Normal University.

Hughes, A. (1989) Testing for language teachers. Cambridge: Cambridge University Press

Khaniya, T. R. (1990). Examinations as instruments for educational change: Investigating the washback effect of the Nepalese English exams. $\mathrm{PhD}$ thesis, University of Edinburg.

Madaus, G.F. (1988). The influence of testing on the curriculum. In Tanner, L.N. (ed). Critical issues in curriculum. Eighty-seventh yearbook of the National Society for the Study of Education. Chicago: University of Chicago Press.

McEwen, N. (1995). Educational accountability in Alberta Canadian Journal of Education, 20(4), 27-44.

Mizutani, S. (2009). The mechanism of washback on teaching and learning. PhD thesis, University of Auckland.

Oduro-Okyireh, G. \& Narh-Kwao, D. L. P. (2014). Effects of assessment on classroom learning in senior high schools in the Ashanti Mampong Municipality of the Ashanti Region of Ghana. The International Journal of 
Humanities \& Social Studies. Vol 2 Issue 7, pp. 150-155.

Ofori-Bekoe, S. (2006). Assessment and curriculum goals and objectives: Evaluation of the systemic impact of the SSSCE on the senior school Social Studies curriculum in Ghana. Unpublished PhD Thesis, University of Strathclyde.

Onaiba, A. B. E. (2013). Investigating the Washback Effect of a Revised EFL Public Examination on Teachers' Instructional Practices, Materials and Curriculum. Unpublished Doctor of Education thesis in Applied Linguistics and TESOL. University of Leicester.

Pearson, I. (1988). Tests as levers for change. In D. Chamberlain \& R. J. Baumgardner (Eds.), ESP in the classroom: Practice and evaluation (pp. 98-107). London: Modern English.

Peng, Y. (2011). The new teaching requirements and the influence of assessment: A case study of college English reform in China. PhD thesis. University of Huddersfield.

Popham, W. J. (1987). The merits of measurement-driven instruction. Phi Delta Kappa, 68(9), 679-682.

Powers, D. E. (2010). The case for a comprehensive, four-skills assessment of English-Language proficiency. $R \& D$ Connections No. 14. Available at www.ets.org/Media/Research/pdf/RD_Connections14.pdf. Retrieved: October 2, 2014

Scott, C. (2007). Stakeholder perceptions of test impact. Assessment in Education: Principles, Policy \& Practice, $14(1), 27-49$.

Shih, C. (2007). A new washback model of students' learning. The Canadian Modern Language Review. 64 (1), $135-162$

Shohamy, E., Donitsa-Schmidt, S., \& Ferman, I. (1996). Test impact revisited: Washback effect over time. Language Testing, 13(3), 298-317.

Spolsky, B. (1994). The examination of classroom backwash cycle: Some historical cases. In Nunan, D, Berry, V and Berry, R. (Eds) Bringing about Change in Language Education, University of Hong Kong, Dept. of Curriculum Studies, Hong Kong.

Spratt, M. (2005). Washback and the classroom: the implications for teaching and learning of studies of washback from exams. Language Teaching Research 9, 1, pp. 5-29

Wall, D. (1996). Introducing new tests into traditional systems: insights from general education and from innovation theory. Language Testing, 13(3), 334-354.

Watanabe, Y. J. (1996) Does grammar-translation come from entrance examination? Language Testing 13(3), 318333

Wrenn, J. \& Wrenn, B (2009). Enhancing learning by integrating theory and practice. International Journal of Teaching and Learning in Higher Education. Vol. 21, No2, 258-265

Vernon, P. E. (1956). The measurement of abilities. London: London University Press. 


\section{Appendix 1}

QUESTIONNAIRE FOR STUDENTS

Institution:

Class:

Please complete the following questionnaire by placing a CROSS $(\mathbf{X})$ in the appropriate box.

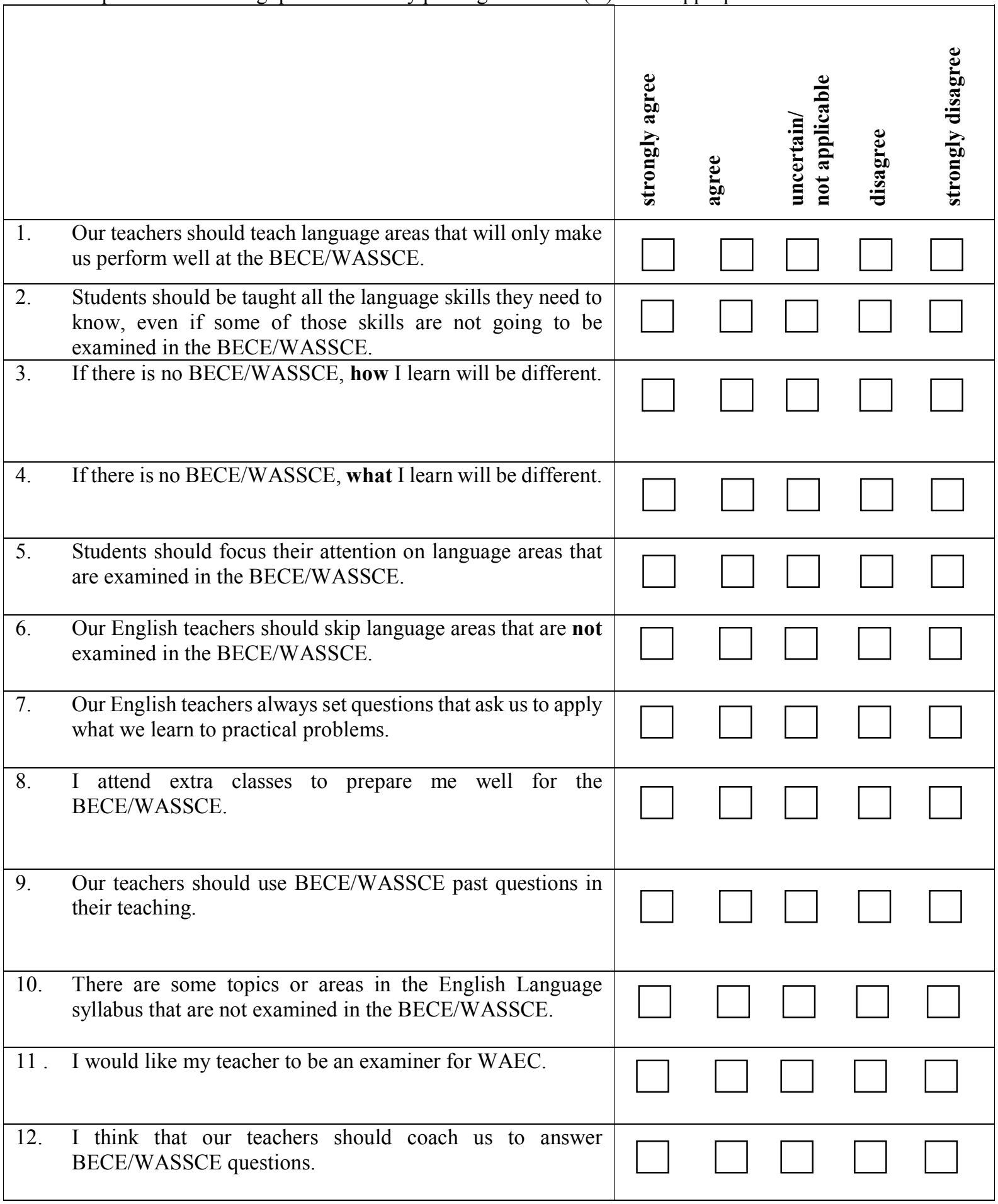




\begin{tabular}{l} 
13. I am always anxious about the BECE/WASSCE. \\
\hline 14. $\quad$ I often try my hands at BECE/WASSCE past questions. \\
all class tests and mock examinations to make us familiar \\
with the questions.
\end{tabular}

21. Why is it necessary to learn English language at the junior/senior high school level?

22. How does the BECE/WASSCE influence the way you learn English language?

23. Do you like the way your English teacher teaches you? Explain.

24. Does your English teacher teach you some topics or language skills that are not examined in the BECE/WASSCE?

25. Describe the topics or language skills that you don't like, and why.

26. How would you learn English language if there was no BECE/WASSCE? 
28. How is your learning in JHS3/SHS3 different from that of JHS1/SHS1 in relation to preparation for the $\mathrm{BECE} / \mathrm{WASSCE}$ English language test?

\section{Appendix 2}

\section{INTERVIEW GUIDE WITH STUDENTS}

1. Why is it necessary to learn English language at the junior/senior high school level?

2. How does the BECE/WASSCE influence the way you learn English language?

3. Are conversant with the demands of the BECE/WASSCE?

4. Are there some topics or areas in the English Language syllabus that are not examined in the BECE/WASSCE?

5. Does your English teacher teach you some topics or language skills that are not examined in the BECE/WASSCE?

6. Do you expect your English teacher to direct instruction toward the BECE/WASSCE?

7. It is said that examinations are not necessary. What is your view about examinations in general?

8. Have you tried to answer any past BECE/WASSCE questions on your own? Can you explain why?

9. Does your English teacher use past questions in his/her lessons or in his/her class tests?

10. How are you preparing for the BECE/WASSCE?

11. How would you learn English language if there was no BECE/WASSCE? 